\title{
Systematic review and meta-analysis of tumor biomarkers in predicting prognosis in esophageal cancer
}

\author{
Meilan Chen, Jizheng Huang, Zhenli Zhu, Jun Zhang and Ke Li*
}

\begin{abstract}
Background: Esophageal cancer (EC) is a frequently occurring cancer with poor prognosis despite combined therapeutic strategies. Many biomarkers have been proposed as predictors of adverse events. We sought to assess the prognostic value of biomarkers in predicting the overall survival of esophageal cancer and to help guide personalized cancer treatment to give patients the best chance at remission.

Methods: We conducted a systematic review and meta-analysis of the published literature to summarize evidence for the discriminatory ability of prognostic biomarkers for esophageal cancer. Relevant literature was identified using the PubMed database on April 11, 2012, and conformed to the REMARK criteria. The primary endpoint was overall survival and data were synthesized with hazard ratios (HRs).

Results: We included 109 studies, exploring 13 different biomarkers, which were subjected to quantitative meta-analysis. Promising markers that emerged for the prediction of overall survival in esophageal squamous cell cancer included VEGF (18 eligible studies, $\mathrm{n}=1476, \mathrm{HR}=1.85,95 \% \mathrm{Cl}, 1.55-2.21$ ), cyclin D1 (12 eligible studies, $\mathrm{n}=1476, \mathrm{HR}=1.82,95 \% \mathrm{Cl}$, 1.50-2.20), Ki-67 (3 eligible studies, $\mathrm{n}=308, \mathrm{HR}=1.11,95 \% \mathrm{Cl}, 0.70-1.78$ ) and squamous cell carcinoma antigen (5 eligible studies, $\mathrm{n}=700, \mathrm{HR}=1.28,95 \% \mathrm{Cl}, 0.97-1.69$ ); prognostic markers for esophageal adenocarcinoma included COX-2 (2 eligible studies, $\mathrm{n}=235, \mathrm{HR}=3.06,95 \% \mathrm{Cl}, 2.01-4.65$ ) and HER-2 (3 eligible studies, $\mathrm{n}=291$, $H R=2.15,95 \% \mathrm{Cl}, 1.39-3.33$ ); prognostic markers for uncategorized ECs included $\mathrm{p} 21$ (9 eligible studies, $\mathrm{n}=858$, $\mathrm{HR}=1.27,95 \% \mathrm{Cl}, 0.75-2.16$ ), p53 (31 eligible studies, $\mathrm{n}=2851, \mathrm{HR}=1.34,95 \% \mathrm{Cl}, 1.21-1.48$ ), $\mathrm{CRP}$ (8 eligible studies, $\mathrm{n}=1382, \mathrm{HR}=2.65,95 \% \mathrm{Cl}, 1.64-4.27$ ) and hemoglobin (5 eligible studies, $\mathrm{n}=544, \mathrm{HR}=0.91,95 \% \mathrm{Cl}, 0.83-1.00$ ).
\end{abstract}

Conclusions: Although some modest bias cannot be excluded, this review supports the involvement of biomarkers to be associated with EC overall survival.

Keywords: Esophageal cancer, Tumor biomarkers, Prognosis, Survival, Meta-analysis

\section{Background}

Esophageal cancer (EC), which accounted for 482,300 new cases of cancer in 2008, is the eighth most common cancer worldwide, and has the sixth highest incidence of cancer mortality, with 406,800 deaths registered [1]. Although the prevalence is highest in Africa and Asia, the incidence of adenocarcinoma is rising in western countries and the America [2-4]. Surgery, combined with neoadjuvant radiation and chemotherapy, or even neoadjuvant chemoradiotherapy, remains the only curative modality for

\footnotetext{
*Correspondence: kli@stu.edu.cn

Department of Preventive Medicine, Shantou University Medical College, No.22 Xinling Road, Shantou, Guangdong 515041, China
}

EC. However, the long-term prognosis of patients undergoing potentially curative esophageal resection is still poor, with the reported 5-year survival rate being 9.8\% [5]. Commonly used classification systems utilize histological type to group EC into two main categories: esophageal squamous cell carcinoma (ESCC) and adenocarcinoma (EADC). ESCC can occur in all parts of the esophagus, whereas EADC arises mostly via metaplasia of the epithelium of the distal esophagus. Published studies of EC may not distinguish between ESCC and EADC.

The ability to predict patients with poor prognosis would help guide surgery and adjuvant treatment according to individual risk. Attempts have been made to
C Biomed Central

(c) 2013 Chen et al.; licensee BioMed Central Ltd. This is an open access article distributed under the terms of the Creative Commons Attribution License (http://creativecommons.org/licenses/by/2.0), which permits unrestricted use, distribution, and reproduction in any medium, provided the original work is properly cited. 
predict poor prognosis in patients with EC using clinicopathological characteristics. Age, tumor stage distribution, tumor histology and body mass index have all been found to predict survival [6-8]. The ability to predict tumor behavior on the basis of molecular markers from either biopsy or serum samples would help inform the patients and clinician during the decision-making process. With advances in the understanding of tumor biology, there is sufficient new evidence available to gain further insight into this disease. In addition, biomarkers of prognostic significance, may present novel therapeutic targets.

The aim of this study was to summarize the results of published studies regarding the prognostic role of the molecular markers in EC. In this review, we prioritized the available data, in all included surveys, according to either the REMARK (Reporting recommendations for tumor MARKer prognostic studies) study design or methodological assessment quality metrics [9]. Many variations exist in the experimental methods chosen and procedures used, including antigen retrieval observed variability in staining pattern description, cut-off point selection, and assignment of specimens to categories, that influence the prognostic value of the proposed association. Because new biomarkers should enhance the current routine prognostic markers to be adopted for use in the clinic, studies that do not extend their statistical analysis beyond univariate survival measures are less valuable than studies that do. We sought to determine candidate biomarkers with sufficient evidence to support prospective validation in a controlled clinical environment and to identify functional pathways for which data either suggest a lack of involvement in EC prognosis or the need for additional investigation due to insufficient rigor among the previously conducted studies. We identified a subset of candidate predictors of EC outcome from the published literature that were evaluated according to robust sampling and laboratory methods.

\section{Methods}

\section{Search strategy}

To identify all primary research studies that evaluated levels of candidate biomarker expression as a prognostic factor among individuals with EC, we searched the PubMed medical literature database up to April 11, 2012, without language restrictions, using a strategy developed with an expert librarian based on terms for esophageal carcinoma, prognostic studies [10] and biomarkers. The search strategy was based on combinations of ("esophageal" or "esophagus"), ("neoplasms" or "carcinoma" or "tumor"), (gene or protein or biomarker or marker), and (prognos* or "survival analysis" [Mesh] or "follow-up studies" [Mesh] or mortality [Majr] or mortality[subheading] or incidence [Mesh] or predict or course or outcome). One reviewer (M. Chen) obtained the full texts of relevant articles following the search and inspection of titles and abstracts of citations to identify those articles that were likely to report the study of prognostic biomarkers in EC. In cases where data in several publications were derived from part or all of the same patient series, only the study presenting the most recent or most complete dataset was included.

\section{Methodology and validity assessment}

We used published guidelines for reporting tumor marker studies and quality metrics for evaluating studies to include in the cancer-related meta-analyses $[9,11]$. Criteria used to determine study eligibility were as follows: 1) a prospective or retrospective cohort design with a welldefined study population and justification for all excluded eligible cases, 2) assay of the primary EC specimens, 3) a clear description of methods for specimen handling and testing, including selection and preparation of reagents or kits, as well as visualization techniques, 4) clear statements on the choice of positive/present and negative/absent controls and on assay validation, 5) statistical analysis using multivariable proportional hazards modeling that adjusted for clinical prognostic factors, and 6) reporting of the resultant adjusted hazard ratios (HRs) and their 95\% confidence intervals (CIs), or provision of data available for statistical estimation of HRs. Because esophageal small cell carcinomas, epidermoid cancer of the esophagus, and neuroendocrine carcinoma of the esophagus have different clinical courses, studies that did not distinguish these tumor types from EC were excluded.

Quality assessment was performed in duplicated for each eligible study by two independent reviewers (Chen and Huang) using operationalized prognostic biomarker reporting guidelines [9] and extract details on 16 items (Additional file 1: Table S1). This scale allowed for assessment of study design, biomarker measurement, outcome and analysis.

\section{Data extraction}

Two investigators (Chen and Zhu) reviewed all eligible studies and carefully extracted study characteristics in duplicate, including the first author's name, publication year, country of origin, histology, sample size, gender, mean/median age, disease stage, test method, cutoff value, the status of biomarker expression, and the computed multivariable hazard ratio and its $95 \%$ CI. When results were present without confidence intervals, the $\mathrm{p}$ value was used to estimate the confidence intervals via the $\mathrm{z}$-statistic.

\section{Statistical methods}

All eligible individual biomarker assays were sorted according to their major biological function. Function was determined by reviewing the current scientific literature comprehensively and then classifying according to the 5 acquired capabilities of cancer as defined by Hanahan 
and Weinberg [12], and which included sustained angiogenesis, evasion of apoptosis, insensitivity to antigrowth signals, limitless replicative potential and tissue invasion and metastasis. To accommodate blood biomarkers, the Hanahan-Weinberg classification system was supplemented by one additional category: serum markers. Biomarkers evaluated in less than five studies, were excluded in this review and out of quantitative synthesis. For biomarkers assayed in five or more studies, the summary HR and 95\% CI were calculated by using fixed effects according to generic inverse variance and random effects model using the DerSimonian-Laird method [13]. Statistical heterogeneity among studies was assessed using Q and $\mathrm{I}^{2}$ statistics [14]. We considered that heterogeneity was present when the Q-test P-value was less than 0.1. In addition, when $\mathrm{I}^{2}$ was lower than $50 \%$, studies with an acceptable heterogeneity were considered, and the fixedeffects model was used; otherwise, a random effect model was adopted. The combined HRs were estimated graphically by Forest plots. Possible source of heterogeneity were investigated by subgroup analysis. Study publication bias was assessed with counter-enhanced funnel plots, by Begg's adjusted rank correlation test and by Egger's regression asymmetry test [15-17]. When $\mathrm{p}>0.05$ was considered to indicate that there was no publication bias in the studies. All statistical analysis was conducted using Stata SE 11.0 software (Stata Corporation).

\section{Results}

\section{Eligible studies}

The abstracts and titles of 3259 primary manuscripts were identified for initial review using strategies as described. Reviewers identified 979 manuscripts to be appropriate in terms of evaluation of prognostic biomarkers in EC. For these manuscripts, full-text articles were obtained. Upon further review, 109 studies published between 1994 and 2012 were eligible for this systematic review and with meta-analysis (Figure 1).

All reported the prognostic value of biomarkers in patients with EC by presenting multivariable survival estimates for differential levels of candidate biomarker expression. Effective sample size ranged from 29 [18] to 708 patients [19] (median, 87 patients), with 13 studies including 50 or fewer patients, 54 studies including 51100 individuals, 26 studies including 101-150 individuals, 12 studies including 151-300 individuals and 4 studies including more than 300 individuals. Seventeen clinicopathologic factors were incorporated in one or more of the eligible studies' multivariate analysis. The most commonly included prognostic factor was depth of invasion involvement with lymph node status being included in 67 (61\%) studies and 65 (59\%) studies. Other common adjustment parameters included tumor stage (37 of 109 studies), gender (27 of 109 studies) and metastatic status
(27 of 109 studies) (Figure 2A). Fifty-seven studies considered three to five clinical parameters in their multivariable proportional hazards models, 26 studies considered less than three covariates, 21 studies included more than five covariates and another 5 studies did not report (Figure 2B).

These 109 studies presented data on 13 unique biomarkers. The majority of eligible studies $(n=87)$ restricted their analysis to a single included candidate marker, and the remaining 22 evaluated between two to five markers. Regarding angiogenesis, 6 studies of cyclooxygenase- 2 (COX-2) [20-25] and 19 studies of vascular endothelial growth factor (VEGF) [26-44] were included. Of the eligible marker associated with apoptosis, 5 studies of survivin [45-49] were available for analysis. For cellcycle regulators, 9 studies of p21 [27,50-57] and 7 studies of p27 [25,58-63] were included. Four markers associated with replicative potential were eligible for examination, and were comprised of 15 studies of cyclin D1 [27,51,54,58,59,62,64-72], 32 eligible studies of p53 [27,30,32,34,38,40,51,54,68,73-95], 6 studies of human epidermal growth factor receptor-2 (HER-2) [19,96-100] and 5 studies of Ki67 [25,27,87,101,102]. Regarding the tissue invasion and metastasis markers evaluated, 10 studies of E-cadherin [27,65,102-109] were included. Three eligible serum markers were eligible for analysis, and were comprised of 8 studies of $C$ reative protein (CRP) [110-117], 5 studies of SCC-Ag [18,118-121] and 5 studies of hemoglobin $(\mathrm{Hb})$ [122-126]. The 13 biomarkers were evaluated for overall survival (OS) and sorted according to five to eight Hanahan-Weinberg functional capabilities modified to include serum markers (Additional file 2: Table S2). Additional file 2: Table S2 outlines the demographic, clinicopathological, methodological and outcome characteristics of these studies.

\section{Quality of study reports}

The mean number of study quality items reported was 11 out of possible 16 and was not associated with sample size with correlation coefficient of $0.06, \mathrm{p}=0.52$ (Figure 3 ). There was also no statistically significant difference between the quality items of 65 positive studies (where a biomarker was statistically a factor for poor prognosis) and 44 negative studies (where a biomarker was not statistically significant) (Mann-Whitney $\mathrm{p}=0.27$ ). All of the studies reported details of the clinical endpoint and multivariate analysis. More than $90 \%$ of studies reported details of the objective or prespecified hypothesis, patient source, population characteristics, assay method, manufacturer, cutpoint and confounders. Of note, 63 studies reported the followup period or the median follow-up time. One study referred to a missing value, but no study referred to a statistical sample size. To try to evaluate the impact of study quality on the final pooled estimate, a subgroup analysis 


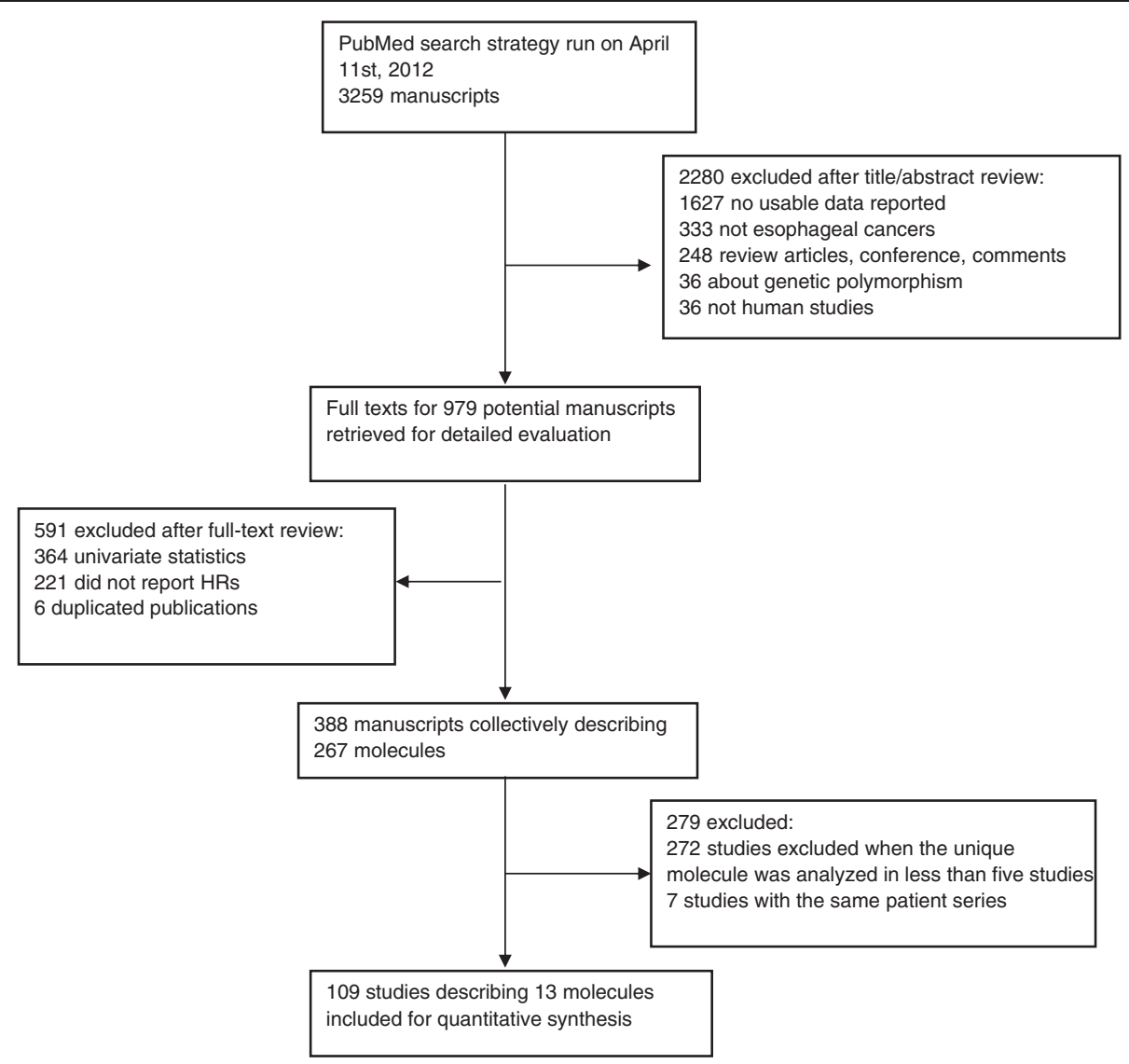

Figure 1 Flow diagram of the literature search and selection of eligible studies.

was performed according to the different number of quality items: eleven or more eleven, which is the mean number of study quality items, and less than eleven. For majority markers, the results were consistent, the pooled HRs were not significantly altered, suggesting the study quality improbable as source of bias. For COX-2, only one study with quality items less than eleven, the HR was reported 2.34 (95\% CI, 1.11-4.91). The pooled HR estimated for the other five studies was 1.36 (95\% CI, 0.60-3.08), which is similar to the final pooled HR 1.54 (95\% CI, 0.802.98). For HER-2, both subgroups included three studies eligible for meta-analysis, with combined HR 1.64 (95\% CI,1.07-2.51) and 1.26 (95\% CI, 0.70-2.26), respectively. Because of a small number of studies included, the results should be treated with caution.

\section{Meta-analysis results for biomarkers}

For the 13 markers, a multivariate HR and 95\% CI were available from five or more studies and were combined using both fixed effects general inverse variance and DerSimonian-Laird random effects modeling to obtain a single summary HR and 95\% CI. (Table 1) Five of the six original Hanahan-Weinberg functional capabilities along with the additional group were represented by at least one marker statistically associated with OS. Two studies $[35,91]$ were excluded which failed to present validated data in their meta-analysis.

\section{COX-2, VEGF}

Of the six studies that used immunohistochemistry (IHC) for OS data, the pooled HR was 1.54 (95\% CI, $0.80-2.98)$, with significant evidence of heterogeneity between the contributing studies $\left(\mathrm{I}^{2}=75 \%\right)$. Restricting analysis to the four studies assessing COX-2 expression in ESCC, the pooled HR was 0.96 (95\% CI,0.39-2.41), again, with evidence of study heterogeneity $(73.5 \%)$. These results should, however, be interpreted with caution because of the small number of contributing studies and the significant evidence for significant study heterogeneity. Two studies assessed COX-2 expression in EADC displayed a pooled HR of 3.06 (95\% CI, 2.01-4.65), with no evidence of heterogeneity $\left(\mathrm{I}^{2}=0.0\right)$.

Of the eighteen VEGF expression studies eligible for pooling of OS data, the pooled HR was 1.80 (95\% CI, 1.51-2.14) with no evidence of heterogeneity. The Forrest plot for this analysis is shown in Figure 4A. When 

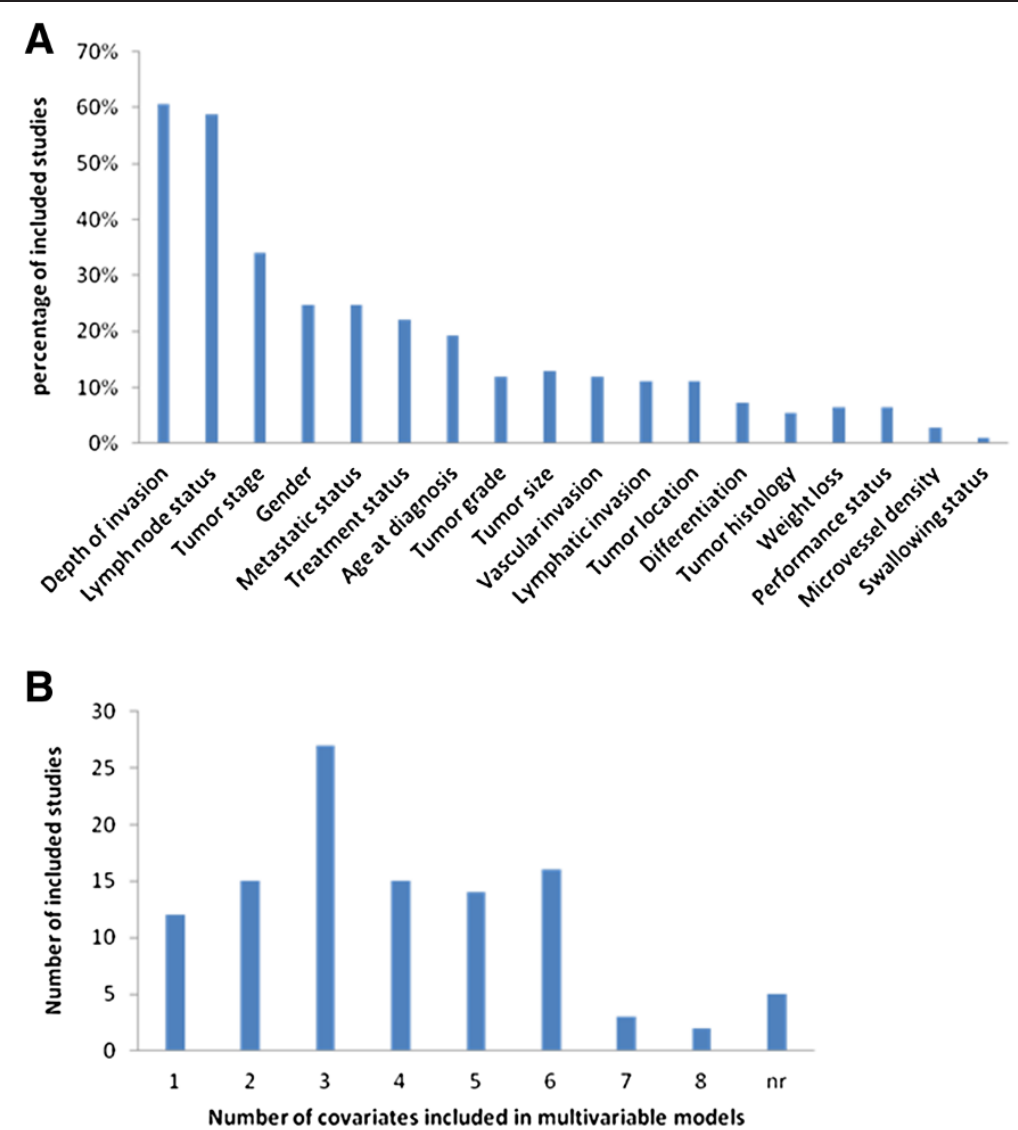

Figure $\mathbf{2}$ Characteristics of included studies in the systematic review. A. Frequencies with which adjustments were made for various clinicopathologic parameters. B. Distributions of the total number of clinicopathologic covariates that were adjusted for across the 109 eligible studies. NOTE: nr, not report.

restricting analysis to the sixteen studies examining VEGF expression in ESCC, the combined HR was 1.85 (95\% CI, 1.55-2.21) with no evidence of heterogeneity. Of the other two studies, one presented data on EC and one on EADC, respectively. To assess the effect of four methods on evaluating VEGF expression, we pooled HRs from studies using IHC, enzyme-linked immunosorbent assay (ELISA) or reverse transcription polymerase chain reaction (RTPCR). ELISA-based studies demonstrated a larger pooled HR (HR 2.55, 95\% CI, 1.72-3.79) compared to IHC-based studies (HR 1.59, 95\% CI, 1.28-1.98) or RTPCR-based (HR 1.90, 95\% CI, 1.24-2.91) studies.

\section{Survivin}

For five studies evaluating survivin expression in esophageal cancers, the combined HR was 1.90 (95\% CI, 1.06$3.40)$ and there was evidence for heterogeneity $\left(\mathrm{I}^{2}=\right.$ 74.6\%). The pooled HR estimated for survival in the four IHC-based studies involving ESCC was 1.57 (95\% CI, 0.91-2.69), again, with significant evidence of heterogeneity $\left(\mathrm{I}^{2}=70.7 \%\right)$. The remaining PCR-based study involved EC, and had an HR of 6.60 (95\% CI, 1.97-22.12). p21, p27

Nine studies examined p21 and seven studies assessed p27 levels with the pooled HRs of 1.27 (95\% CI, 0.752.16) and 1.68 (95\% CI, 0.90-3.12), respectively, and there was evidence of heterogeneity within both groups. All studies used IHC to estimate the correlation between biomarker expression and survival. Interestingly, when grouped according to the histology of individual studies, the combined HR in ESCC for p21 (seven studies), remained unchanged at 1.28 (95\% CI, 0.70-2.33). The pooled HR for p27 (six studies) in ESCC was 1.97 (95\% CI, 1.003.88). In both analyses, there was significant evidence of study heterogeneity $\left(\mathrm{I}^{2}=87.4 \%\right.$ for $\mathrm{p} 21$ and $\mathrm{I}^{2}=74.6 \%$ for p27, respectively).

\section{Cyclin D1, HER-2, Ki-67, p53}

Fifteen studies assessed cyclin D1. The overall pooled HR was 1.73 (95\% CI, 1.34-2.23) and there appeared to be some heterogeneity between the studies $\left(\mathrm{I}^{2}=56.3 \%\right)$ Figure 4B illustrates the Forrest plot for the pooled data. In subgroup analysis, the pooled HR for ESCC was 1.82 (95\% CI, 1.50-2.20) with no evidence of heterogeneity. 


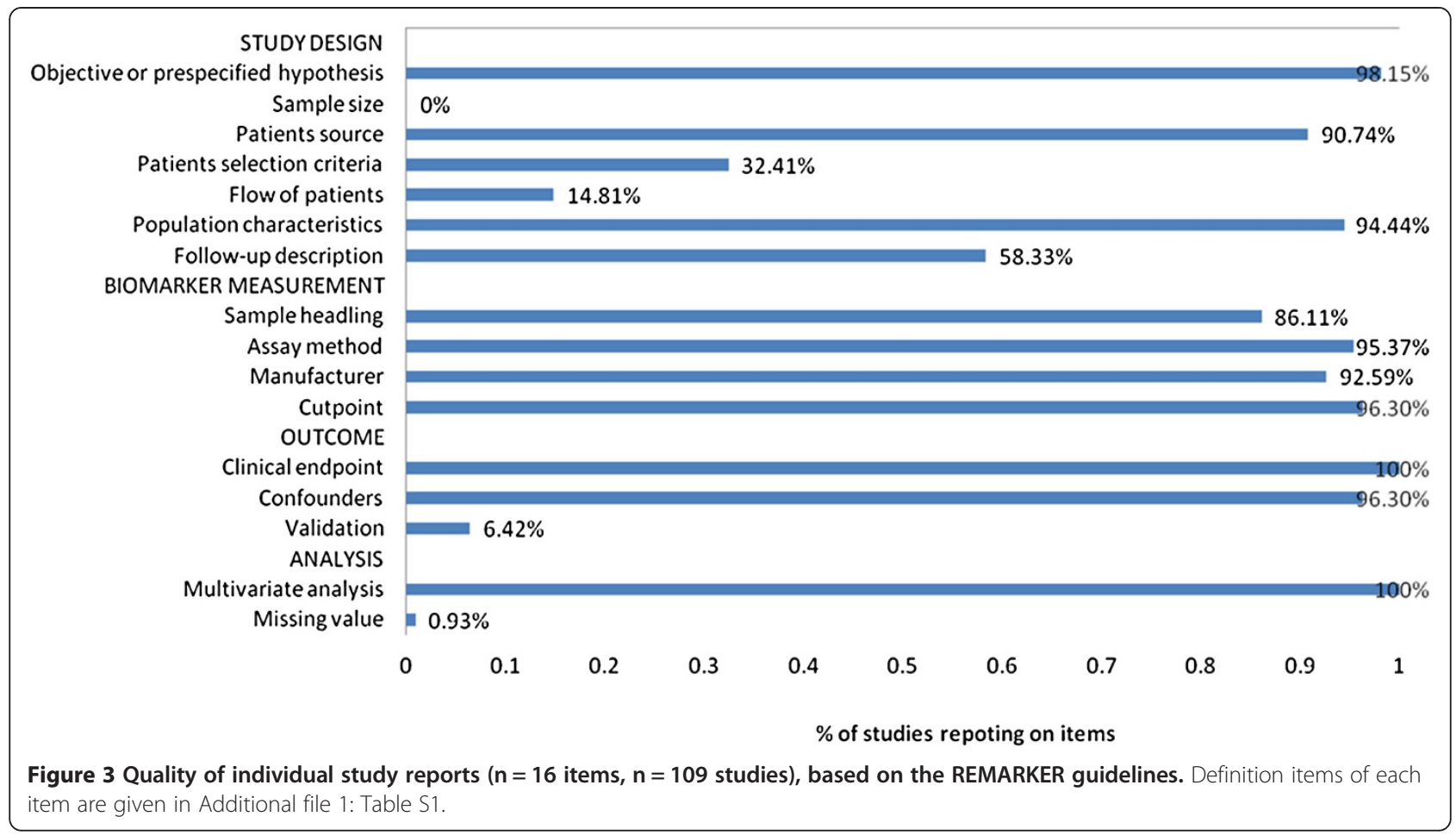

Only three of the fifteen studies presented data evaluable for assessment of EC and the pooled HR was 1.18 (95\% CI, 0.57-2.45). However, this result should be interpreted with caution because of the small number of contributing studies and evidence for significant study heterogeneity $\left(\mathrm{I}^{2}=77.4 \%\right)$. To assess the effect of the method used to assess cyclin D1 expression, HRs, using either IHC or PCR, were pooled. This presented a large pooled HR for PCR-based studies (HR 2.62, 95\% CI, 1.41-4.89) compared to that from the IHC-based studies (HR, 1.64, 95\% CI, 1.26-2.14). The IHC-based group displayed significant heterogeneity, whereas the PCR-based group did not.

Six studies examined the HER-2 as a biomarker. When conducting subgroup analysis, we found three of six eligible studies assessed HER-2 expression in EADC and had a pooled HR of 2.15 (95\% CI, 1.39-3.33) with no evidence of heterogeneity. Two studies assessed HER-2 expression in an EC setting with a pooled HR of 0.91 (95\% CI, 0.73-1.12). Another study examined HER-2 in ESCC and reported an HR of 0.92 (95\% CI, 0.35-2.41). Because of the small number of studies included, the results should be treated with caution.

Three of five studies eligible for assessing Ki-67 in ESCC demonstrated a pooled HR of 1.11 (95\% CI, 0.701.78) with no significant of heterogeneity. None of the HR reported were statistically significant except in one study that assessed in EADC and reported an HR of 0.26 (95\% CI, 0.11-0.60).
Thirty-one studies assessed p53. The pooled HR of 1.34 (95\% CI, 1.21-1.48) revealed significant association with overall survival and the Forest plot for this analysis is shown in Figure 4C. Restricting analysis to the twenty studies assessing p53 expression in ESCC gave a pooled HR of 1.26 (95\% CI, 1.11-1.42), with ELISA-based studies giving a larger pooled HR $(2.13,95 \% \mathrm{CI}, 1.46-3.09)$ than IHC-based studies (HR, 1.25, 95\% CI, 1.12-1.40).

\section{E-cadherin}

Ten studies assessing the E-cadherin biomarker displayed a pooled HR of 1.13 (95\% CI, 1.06-1.21) with evidence of heterogeneity (Forrest plot in Figure 4D). When restricting analysis to the seven studies examing E-cadherin in ESCC, however, the result remained unchanged, with an HR of 1.12 (95\% CI, 1.05-1.19), again, with significant heterogeneity. For the two studies assessing E-cadherin expression in EC, the pooled HR was 1.41 (95\% CI, 1.05-1.89), and there appeared to be no heterogeneity between the studies. An EADC study reported an HR of 3.30 (95\% CI, 0.99-10.99). When grouped according to method, the combined HR of IHC-based studies was 1.28 (95\% CI, 1.11-1.49) with significant heterogeneity. The only ELISA-based study reported an HR of 1.10 (95\% CI, 1.02-1.18).

\section{SCC-Ag, CRP, Hb}

Five eligible studies assessed SCC-Ag expression by enzyme immunoassay (EIA) in ESCC, and the pooled HR 
Table 1 Summary of the multivariable hazard ratios and $95 \% \mathrm{Cl}$ for eligible biomarkers, organized according to the Hanahan-Weinberg functional capability

\begin{tabular}{|c|c|c|c|c|c|c|}
\hline Biomarker & Group & No. of studies & Patients & I-V HR(95\% Cl) & $\mathrm{D}+\mathrm{L} \mathrm{HR}(95 \% \mathrm{Cl})$ & $I^{2}(\%)$ \\
\hline \multicolumn{7}{|c|}{ Angiogenesis } \\
\hline \multirow[t]{3}{*}{ cox-2 } & Total(IHC) & 6 & 469 & $2.00(1.47-2.71)$ & $1.54(0.80-2.98)$ & 75.0 \\
\hline & ESCC & 4 & 234 & $1.23(0.79-1.93)$ & $0.96(0.39-2.41)$ & 73.5 \\
\hline & EADC & 2 & 235 & $3.06(2.01-4.65)$ & $3.06(2.01-4.65)$ & 0.0 \\
\hline \multirow[t]{7}{*}{ VEGF } & Total & 18 & 1476 & $1.80(1.51-2.14)$ & $1.76(1.38-2.24)$ & 43.5 \\
\hline & ESCC & 16 & 1329 & $1.85(1.55-2.21)$ & $1.84(1.45-2.33)$ & 38.4 \\
\hline & EADC & 1 & 38 & $0.37(0.10-1.40)$ & $0.37(0.10-1.40)$ & - \\
\hline & EC & 1 & 109 & $1.80(0.70-4.65)$ & $1.80(0.70-4.65)$ & - \\
\hline & $\mathrm{IHC}$ & 14 & 1109 & $1.59(1.28-1.98)$ & $1.56(1.16-2.12)$ & 43.6 \\
\hline & ELISA & 2 & 179 & $2.55(1.72-3.79)$ & $2.67(1.57-4.54)$ & 36.8 \\
\hline & RTPCR & 2 & 188 & $1.90(1.24-2.91)$ & $1.90(1.24-2.91)$ & 0.0 \\
\hline \multicolumn{7}{|c|}{ Evading apoptosis } \\
\hline \multirow[t]{3}{*}{ survivin } & Total & 5 & 357 & $1.60(1.23-2.07)$ & $1.90(1.06-3.40)$ & 74.6 \\
\hline & $\mathrm{ESCC}(\mathrm{IHC})$ & 4 & 295 & $1.50(1.15-1.95)$ & $1.57(0.91-2.69)$ & 70.7 \\
\hline & $E C(P C R)$ & 1 & 62 & $6.60(1.97-22.12)$ & $6.60(1.97-22.12)$ & - \\
\hline \multicolumn{7}{|c|}{ Insensitivity to antigrowth signal } \\
\hline \multirow[t]{3}{*}{ p21 } & Total(IHC) & 9 & 858 & $0.90(0.75-1.08)$ & $1.27(0.75-2.16)$ & 86.4 \\
\hline & ESCC & 7 & 683 & $0.90(0.74-1.09)$ & $1.28(0.70-2.33)$ & 87.4 \\
\hline & EC & 2 & 175 & $0.94(0.57-1.53)$ & $1.31(0.22-7.98)$ & 91.2 \\
\hline \multirow[t]{3}{*}{ p27(-) } & Total(IHC) & 7 & 606 & $1.44(1.07-1.92)$ & $1.68(0.90-3.12)$ & 76.4 \\
\hline & ESCC & 6 & 478 & $1.75(1.25-2.44)$ & $1.97(1.00-3.88)$ & 74.6 \\
\hline & EC & 1 & 128 & $0.75(0.41-1.38)$ & $0.75(0.41-1.38)$ & - \\
\hline \multicolumn{7}{|c|}{ Limitless replicative potential } \\
\hline \multirow[t]{5}{*}{ cyclin D1 } & Total & 15 & 1931 & $1.65(1.41-1.93)$ & $1.73(1.34-2.23)$ & 56.3 \\
\hline & ESCC & 12 & 1295 & $1.82(1.50-2.20)$ & $1.89(1.44-2.48)$ & 46.2 \\
\hline & EC & 3 & 636 & $1.37(1.05-1.80)$ & $1.18(0.57-2.45)$ & 77.4 \\
\hline & $\mathrm{IHC}$ & 13 & 1735 & $1.60(1.36-1.88)$ & $1.64(1.26-2.14)$ & 57.9 \\
\hline & $P C R$ & 2 & 196 & $2.62(1.41-4.89)$ & $2.79(1.27-6.14)$ & 18.5 \\
\hline \multirow[t]{7}{*}{ HER-2 } & Total & 6 & 1162 & $1.06(0.88-1.28)$ & $1.37(0.91-2.07)$ & 67.6 \\
\hline & ESCC & 1 & 66 & $0.92(0.35-2.41)$ & $0.92(0.35-2.41)$ & - \\
\hline & EADC & 3 & 291 & $2.15(1.39-3.33)$ & $2.15(1.39-3.33)$ & 0.0 \\
\hline & EC & 2 & 805 & $0.91(0.73-1.12)$ & $0.93(0.70-1.23)$ & 32.3 \\
\hline & $\mathrm{IHC}$ & 4 & 951 & $0.96(0.78-1.17)$ & $1.17(0.72-1.88)$ & 66.3 \\
\hline & $\mathrm{FISH}$ & 1 & 124 & $1.80(0.90-3.60)$ & $1.80(0.90-3.60)$ & - \\
\hline & RPPA & 1 & 87 & $1.97(1.01-3.83)$ & $1.97(1.01-3.83)$ & - \\
\hline \multirow[t]{4}{*}{ Ki-67 } & Total(IHC) & 5 & 424 & $0.84(0.59-1.20)$ & $0.76(0.41-1.42)$ & 62.2 \\
\hline & ESCC & 3 & 308 & $1.11(0.70-1.78)$ & $1.11(0.70-1.78)$ & 0.0 \\
\hline & EADC & 1 & 59 & $0.26(0.11-0.60)$ & $0.26(0.11-0.60)$ & - \\
\hline & EC & 1 & 57 & $1.03(0.49-2.17)$ & $1.03(0.49-2.17)$ & - \\
\hline \multirow[t]{4}{*}{ P53 } & Total & 31 & 2851 & $1.34(1.21-1.48)$ & $1.33(1.14-1.56)$ & 48.7 \\
\hline & ESCC & 20 & 2063 & $1.26(1.11-1.42)$ & $1.25(1.03-1.51)$ & 48.7 \\
\hline & EADC & 2 & 97 & $2.10(1.10-4.03)$ & $2.10(1.10-4.03)$ & 0.0 \\
\hline & $\mathrm{EC}$ & 9 & 691 & $1.53(1.25-1.86)$ & $1.44(1.06-1.94)$ & 50.9 \\
\hline
\end{tabular}


Table 1 Summary of the multivariable hazard ratios and $95 \% \mathrm{Cl}$ for eligible biomarkers, organized according to the Hanahan-Weinberg functional capability (Continued)

\begin{tabular}{|c|c|c|c|c|c|c|}
\hline & $\mathrm{IHC}$ & 22 & 2122 & $1.25(1.12-1.40)$ & $1.20(1.02-1.40)$ & 38.5 \\
\hline & PCR-SSCP & 5 & 383 & $1.75(1.24-2.49)$ & $1.82(0.93-3.56)$ & 70.5 \\
\hline & ELISA & 4 & 346 & $2.13(1.46-3.09)$ & $2.13(1.46-3.09)$ & 0.0 \\
\hline \multicolumn{7}{|c|}{ Tissue invasion and metastasis } \\
\hline \multirow[t]{6}{*}{ E-cadherin(-) } & Total & 10 & 1569 & $1.13(1.06-1.21)$ & $1.30(1.07-1.58)$ & 61.8 \\
\hline & ESCC & 7 & 977 & $1.12(1.05-1.19)$ & $1.24(0.99-1.56)$ & 67.2 \\
\hline & EADC & 1 & 59 & $3.30(0.99-10.99)$ & 3.30(0.99-10.99) & - \\
\hline & EC & 2 & 533 & $1.41(1.05-1.89)$ & $1.41(1.05-1.89)$ & 0.0 \\
\hline & $\mathrm{HC}$ & 9 & 1472 & $1.28(1.11-1.49)$ & $1.39(1.08-1.80)$ & 60.4 \\
\hline & ELISA & 1 & 97 & $1.10(1.02-1.18)$ & $1.10(1.02-1.18)$ & - \\
\hline \multicolumn{7}{|c|}{ Serum markers } \\
\hline \multirow[t]{14}{*}{ SCC-Ag } & Total(ESCC/EIA) & 5 & 700 & $1.28(0.97-1.69)$ & $1.28(0.93-1.76)$ & 16.4 \\
\hline & Total & 8 & 1382 & $1.43(1.27-1.61)$ & $2.65(1.64-4.27)$ & 85.8 \\
\hline & ESCC & 3 & 260 & $2.05(1.33-3.17)$ & $2.77(1.12-6.86)$ & 68.4 \\
\hline & $E C$ & 5 & 1122 & $1.39(1.23-1.57)$ & $2.66(1.44-4.92)$ & 90.1 \\
\hline & LPIA & 1 & 262 & $3.30(2.17-5.01)$ & $3.30(2.17-5.01)$ & - \\
\hline & $\mathrm{HC}$ & 2 & 110 & $4.33(2.02-9.24)$ & $4.33(2.02-9.24)$ & 0.0 \\
\hline & ELISA & 1 & 150 & $1.42(0.83-2.42)$ & $1.42(0.83-2.42)$ & - \\
\hline & CRP-kit & 1 & 356 & $1.52(1.05-2.21)$ & $1.52(1.05-2.21)$ & - \\
\hline & LEHIA & 1 & 291 & $1.18(1.03-1.36)$ & $1.18(1.03-1.36)$ & - \\
\hline & INA & 1 & 123 & $12.12(3.45-42.57)$ & $12.12(3.45-42.57)$ & - \\
\hline & ITA & 1 & 90 & $5.07(1.92-13.41)$ & $5.07(1.92-13.41)$ & - \\
\hline & Total & 5 & 544 & $0.96(0.95-0.98)$ & $0.91(0.83-1.00)$ & 87.1 \\
\hline & ESCC & 2 & 351 & $0.54(0.40-0.74)$ & $0.54(0.40-0.74)$ & 0.0 \\
\hline & EC & 3 & 193 & $0.97(0.95-0.98)$ & $0.96(0.89-1.03)$ & 88.3 \\
\hline
\end{tabular}

NOTE: HR, hazard ratio; $\mathrm{Cl}$, confidence interval. Combined HRs are calculated for the fixed effects general inverse variance (I-V) method and random effects model with DerSimonian and Laird $(D+L)$ method. (-), reduced/negative expression show the higher risk in prognosis. IHC, immunohistochemistry; PCR, polymerase chain reaction; SSCP, single-strand conformation polymorphism; ELISA,enzyme-linked immunosorbent assay; LPIA, latex photometric immunoassay; LEHIA, latex-enhanced homogeneous immunoassay; INA, immunonephelometry; ITA, immunoturbidimetry; RIA, radioimmunoassay; EIA, enzyme immunoassay.

for OS was 1.28 (95\% CI, 0.97-1.69) with no evidence of heterogeneity. Eight studies examined CRP expression with pooled HR 2.65 (95\% CI, 1.64-4.27) and there was a significant heterogeneity. When conducted subgroup analysis, both EC and ESCC group still showed evidence of heterogeneity. When grouped according to different method used to assess CRP expression, two IHC-based studies had pooled HR 4.33 (95\% CI, 2.02-9.24). Other studies used different method reported HR revealing a significant association with poor survival but one ELISAbased study (HR, 1.42, 95\% CI, 0.83-2.42).

Five studies assessed $\mathrm{Hb}$. The pooled $\mathrm{HR}$ was 0.91 (95\% CI, 0.83-1.00) with significant heterogeneity. When restricting analysis to the three studies assessing $\mathrm{Hb}$ levels in EC, the pooled HR was 0.96 (95\% CI, 0.891.03), again, with evidence of heterogeneity. Two studies assessing $\mathrm{Hb}$ levels in ESCC gave a pooled $\mathrm{HR}$ of 0.54 (95\% CI, 0.40-0.74) with no evidence of heterogeneity.
Only one included study reported no significant association with outcome. However, data were not sufficient to determine the prognostic value of $\mathrm{Hb}$ expression in either ESCC or EADC.

\section{Sensitivity analyses}

We performed sensitivity analyses, in which one study was removed at a time, to evaluate the result stability. For COX-2, VEGF, cyclin D1, p53, E-cadherin and SCC$\mathrm{Ag}$, the results indicated that fixed-effects estimates and/ or random effects estimate before and after the deletion of each study were similar at large, suggesting high stability of the meta-analysis results. For survivin and CRP, although the results are consistent with the overall pooled estimates, the influencing single study conducted by S. Mega et al. and Ines Gockel et al. respectively. For other markers, the sensitivity analysis did not indicate high stability of the results due to one or two studies. 


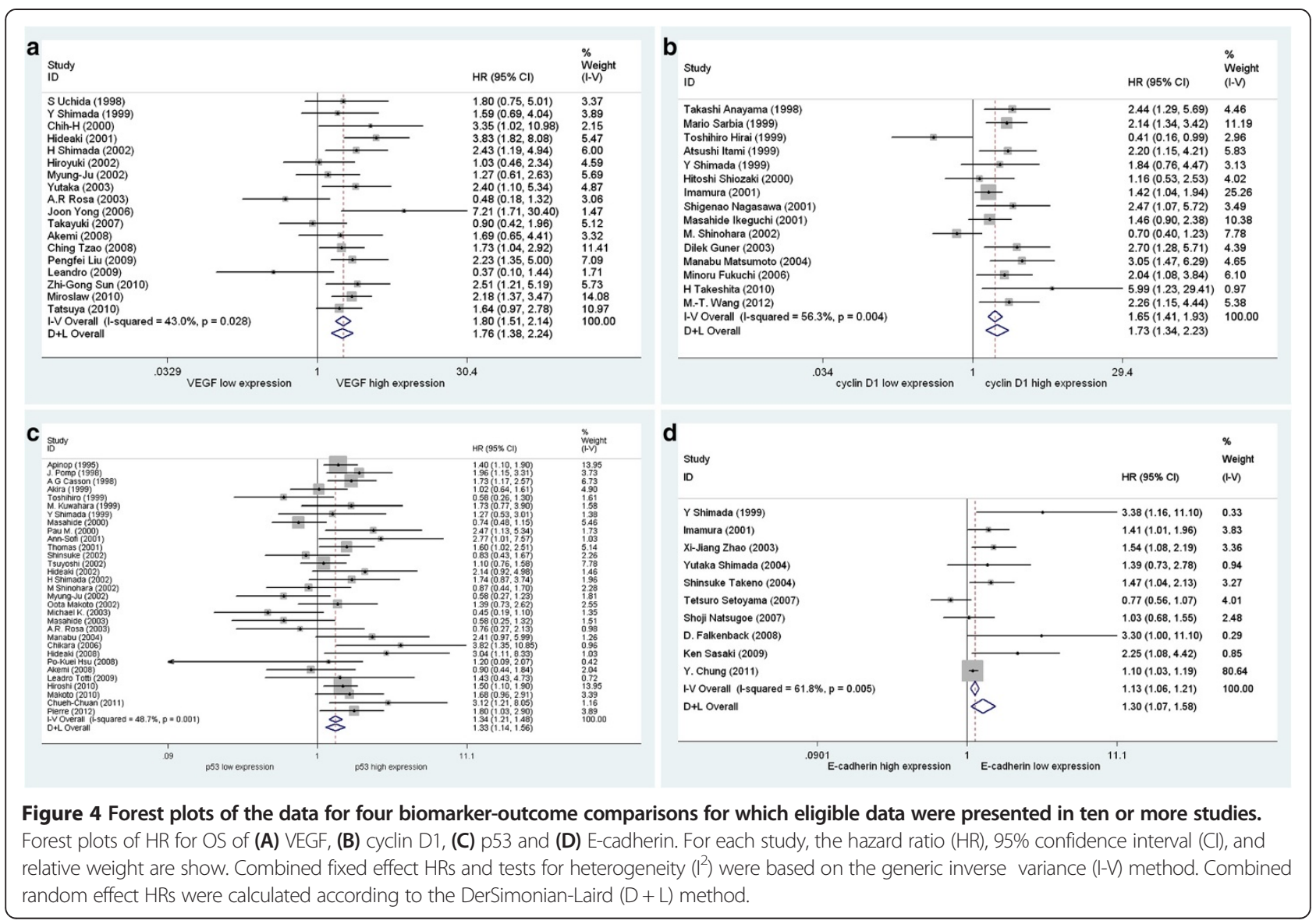

The results of sensitivity analyses are the supplement of the subgroup analysis results.

\section{Publication bias}

Begg's test and Egger's test were used to examine publication bias. There was evidence for significant publication bias with $\mathrm{p} 21$ (Egger's test $\mathrm{p}=0.040$ ), HER-2 (Egger's test $\mathrm{p}=0.042)$ and CRP (Egger's test $\mathrm{p}=0.005)$.

\section{Discussion}

In response to the need for independent prognostic biomarkers for EC that are readily evaluated on routinely acquired clinical specimens, we performed a systematic review and meta-analysis of the published EC literature to identify the molecular markers for which the data support validation as prognostic biomarkers of EC outcome. Using stringent inclusion and exclusion criteria, examining patient selection, and evaluating both laboratory and statistical methodology [9], we identified 109 high-quality studies describing multivariate survival analysis for 13 unique biomarkers. Individual biomarker assay data were organized according to OS, and according to the Hanahan and Wernberg functional groupings that reflect the acquired capabilities of cancer as defined [12].

Quality assessment tools have been developed for prognostic studies to help identify study bias and causes of heterogeneity when performing meta-analysis. We chose to use and operationalize the REMARK reporting guidelines, which provide a useful start for assessing tumor prognostic biomarkers. We find that the studies reported an average of 11 of 16 quality items. Comparison of the quality items of positive and negative studies show no statistically significant difference, allowing meaningful data aggregation. Although this is a relatively new tool, it has been used in other system reviews $[127,128]$.

We demonstrate that COX-2 and VEGF, regulators of angiogenesis, influence overall mortality, indicating the importance of this functional grouping in EC progression. Elevated COX-2 levels may be associated with worse outcome in EADC. Results in the present study demonstrate that, because variability between studies as to be the relative prognostic impact of COX-2 expression in ESSC, the observed survival trend in EADC is concordant with that reported for other malignancies [129]. Because VEGF is a heavily studied marker, the combined 
HR suggests that VEGF over-expression influences OS. This result is concordant with existing reports, which implicate a similar prognostic value for VEGF expression in other malignancies $[130,131]$, and lends further weight to the assertion that angiogenesis is a key determinant in driving EC progression.

Survivin, a strong negative regulator of apoptosis, inhibits or prevents the activation of caspases and promotes cellular survival under otherwise apoptotic conditions [132]. Elevated levels of survivin are significantly associated with poor outcome in multiple studies, as judged by a random effect model.

Cyclin-dependent kinase inhibitors (CKIs) block G1/S phase transition, and decreased expression is thought to result in deregulated growth, promoting tumor progression [133]. Reduced expression of p27 has been shown to be a negative prognostic factor in many malignancies [134]. In the six studies included here, the combined HR demonstrates a significant association between decreased p27 and poor prognosis in ESCC. In contrast, we did not find expression of p21, a p53-inducible universal CKI, to be associated with OS similar to findings by Jaudah and colleagues, who find no correlation between expression of p21 and overall survival in colorectal cancer [135].

Among the four markers associated with limitless replicative potential, cylin D1 and p53 are the most consistently associated with OS. Cyclin D1 is an important cell cycle regulator, being one of the cyclin-dependent kinases, and is controlled from chromosomal region 11q13, which is known to undergo amplification in several cancers, including head and neck cancer. Results again showed a significantly increased likelihood of poor prognosis for ESCC patients when positive for this biomarker. For $\mathrm{p} 53$, the finding that positive expression represents a favorable prognostic feature is consistent with its tumor suppressor function. For Ki-67, a proliferation-associated nuclear protein, only one of five included studies identifies a significant association, failing to support a prognostic role in EC patients, whereas HER-2, a member of epidermal growth factor receptor family, shows association with OS in EADC.

In terms of functional capabilities, markers, involved in facilitating tissue invasion and metastasis, include E-cadherin, whose disappearance is a hallmark of epithelial-mesenchymal transition [136]. E-cadherin is down-regulated in several epithelial malignancies [137]. Ten eligible studies, analyzed here by random effects modeling, further support the prognostic role of E-cadherin loss in OS.

SCC-Ag is a tumor-associated antigen and was originally isolated from a squamous cell carcinoma (SCC). Five studies relating to prognosis in ESSC do not reveal elevated SCC-Ag to be associated with poor survival. The current findings are in agreement with reports for
SCC-Ag in patients with cancers of the cervix and lung $[138,139]$. CRP has been shown to be of prognostic value in many malignancies [140]. We further show that high CRP expression is significantly correlated with poor survival in EC. We report on five studies concerning serum $\mathrm{Hb}$ levels, four of which find that a reduced $\mathrm{Hb}$ level has a significant relationship with decreased survival. Overall, the evidence suggests that serum $\mathrm{Hb}$ measurement is a significant prognostic marker, but the strength of correlation is poor.

The strength of our study lies in the broad, unbiased survey of the available esophageal cancer literature and application of standard systematic review and metaanalysis methods to objectively identify manuscripts with robust data for summarization. However, there are several limitations inherent to our study. By not evaluating redundant study data, we attempted to avoid repeated inclusion of manuscripts from different publications, and focus on studies assessing prognostic markers with standard oncological endpoints of overall survival, while excluding studies with evaluation of recurrence. This study is also limited from the perspective that, for 13 of the eligible markers, summary data across outcome was derived from association data presented in more than four studies, excluding markers represented in included studies fewer than five.

For the included studies, the across-study heterogeneity in the execution of test methods as well as categorization and statistical adjustments for the clinicopathologic factors included in our multivariate analysis may contribute to measurement error of the biomarker to outcome associations. Although most of the authors corrected for established prognostic variables, variations included in adjustment method contribute to inaccuracy related to risk estimation. Variability in assessment of marker expression and cuto-ff point selection across studies may be considered as a potential source of bias. For majority of markers, selection of cut-point to categories marker expression was arbitrary and varied among studies even for the same marker using the same kind of test method. For markers included more than ten studies (VEGF, cyclin D1, p53) for overall survival estimate, stratified analyses was performed according to cut-point value. For VEGF, the choice of the cutoff value for VEGF positivity in IHC (14 studies) varied from 10 to $80 \%$ among studies. Seven studies used 10\% with combined HR 2.03 (95\% CI, 1.51-2.73), this finding is consistent with the pooled $\mathrm{HR}$ 1.80 (95\% CI, 1.51-2.14). In the other groups, the number of studies eligible for estimate is less than five and heterogeneity are significant, so the results should be considered with caution. For cyclin D1 and p53, the situation is similar. Only $10 \%$ group with five or more studies eligible for meta-analysis. Adoption of consensus cutpoints across the esophageal cancer community could facilitate replication 
of results. Additional studies with consistent methodology are needed to define the precise prognostic value of biomarkers.

Publication bias remains a problem in assessing the validity of research studies. Although the power to detect publication bias is reduced when fewer studies are included, when using the Egger's test on our metaanalysis, 10 of 13 biomarkers do not show evidence that publication bias significantly influenced the results. However, analysis of 3 biomarkers (p21, HER-2 and CRP) did display significant publication bias. This may possibly be due to missing data because of unpublished studies. Our review takes into account only published studies. We did not search unpublished studies and abstracts because the methodology we used requires data that are usually only available in full publication studies. Missing information may reflect a negative or more conservative correlation between markers and survival, which could lower the significance of markers expression as a predictor of mortality [141]. Thus, the results for p21, HER-2 and CRP should be treated with considerable caution.

\section{Conclusions}

Research in EC has identified a multitude of molecular markers with a significant role in predicting outcome. In this review, despite the inherent limitations of metaanalysis on prognostic literature, we identify several biomarkers of particular interest that appear to carry prognostic significance. Of 13 biomarkers analyzed, we find VEGF, cyclin D1, Ki-67, and SCC-Ag appeared to hold potential as predictors of outcome in ESCC; COX-2 and HER-2 in EADC; and p21, p53, CRP and Hb in EC. Several biomarkers did not have sufficient data for determination of prognostic value in esophageal cancers. There is a need for biomarker expression and validation of these potential markers in large cohorts of patients. Additional studies with consistent methodology are needed to define the precise prognostic value of biomarkers.

\section{Additional files}

Additional file 1: Table S1. Definitions of 16 items of study reporting quality.

Additional file 2: Table S2. The characteristics of the eligible studies for this systematic review.

\section{Competing interests}

The authors declare that they have no competing interest.

\section{Authors' contributions}

Conception and design: KL and MC; Acquisition of data: all authors; Analysis and interpretation of data: all authors; Manuscript drafting: MC and KL; Manuscript revising: all authors; final approval of this version: all authors. All Authors read and approved the final manuscript.

Acknowledgement

The authors thank Enlin Yu for his technical help with the literature search.

\section{Funding}

The authors received no specific funding for this study.

Received: 11 April 2013 Accepted: 20 September 2013

Published: 11 November 2013

\section{References}

1. Jemal A, Bray F, Center MM, Ferlay J, Ward E, Forman D: Global cancer statistics. CA Canc J Clin 2011, 61:69-90.

2. Kollarova H, Machova L, Horakova D, Janoutova G, Janout V: Epidemiology of esophageal cancer-an overview article. Biomed Papers Med Faculty University Palacky Olomouc Czechoslovakia 2007, 151:17-20.

3. Fau SE, Ward EM, Fau WE, Siegel R, Fau SR, Jemal A, Jemal A: Cancers with increasing incidence trends in the United States: 1999 through 2008. LID - 10.3322/caac.20141 [doi]. CA Canc J Clin 2012, 4:20141.

4. Fau VM, Grande L, Fau GL, Pera M, Pera M: Epidemiology of adenocarcinoma of the esophagus, gastric cardia, and upper gastric third. Recent Results Canc Res 2010, 182:1-17.

5. Gavin AT, Francisci S, Foschi R, Donnelly DW, Lemmens V, Brenner $H$, Anderson LA: Oesophageal cancer survival in Europe: A EUROCARE-4 study. Canc Epidemiol 2012, 36:505-512.

6. Cen P, Banki F, Cheng L, Khalil K, Du XL, Fallon M, Amato RJ, Kaiser LR: Changes in age, stage distribution, and survival of patients with esophageal adenocarcinoma over three decades in the United States. Ann Surg Oncol 2012, 19:1685-1691.

7. Merkow RP, Bilimoria KY, McCarter MD, Chow WB, Gordon HS, Stewart AK, Ko CY, Bentrem DJ: Effect of histologic subtype on treatment and outcomes for esophageal cancer in the United States. Cancer 2012, 118:3268-3276.

8. Fau BR, Lagarde SM, Fau LS, Klinkenbijl JHG, Fau KJ, Busch ORC, Fau BO, van Berge Henegouwen Ml, van Berge Henegouwen Ml: A high body mass index in esophageal cancer patients does not influence postoperative outcome or long-term survival. Ann Surg Oncol 2012, 19:766-771. Epub 2011 Oct 2017.

9. Fau MSL, Altman DG, Fau AD, Sauerbrei W, Fau SW, Taube SE, Fau TS, Gion M, Fau GM, Clark GM, Clark GM: REporting recommendations for tumour MARKer prognostic studies (REMARK). Br J Cancer 2005, 93:387-391.

10. Altman DG: Systematic reviews of evaluations of prognostic variables. BMJ 2001, 323:224-228.

11. Fau SE, Paesmans M, Fau PM, Berghmans T, Fau BT, Branle F, Fau BF, Lemaitre F, Fau LF, Mascaux C, Fau MC, Meert AP, Fau MA, Vallot F, Fau VF, Lafitte JJ, Fau LJ, Sculier JP, Sculier JP: Role of p53 as a prognostic factor for survival in lung cancer: a systematic review of the literature with a meta-analysis. Eur Respir J 2001, 18:705-719.

12. Hanahan D, Weinberg RA: Hallmarks of cancer: the next generation. Cell 2011, 144:646-674

13. DerSimonian R, Laird N: Meta-analysis in clinical trials. Contr Clin Trials 1986, 7:177-188.

14. Higgins JP, Thompson SG, Deeks JJ, Altman DG: Measuring inconsistency in meta-analyses. BMJ 2003, 327:557-560.

15. Fau BC, Mazumdar M, Mazumdar M: Operating characteristics of a rank correlation test for publication bias. Biometrics 1994, 50:1088-1101.

16. Fau SF, Gilbody S, Gilbody S: Bias in meta-analysis detected by a simple, graphical test. Increase in studies of publication bias coincided with increasing use of meta-analysis. BMJ 1998, 316:471.

17. Egger M, Davey Smith G, Schneider M, Minder C: Bias in meta-analysis detected by a simple, graphical test. BMJ 1997, 315:629-634.

18. Fau NY, Shimada H, Fau SH, Okazumi S, Fau OS, Matsubara H, Fau MH, Gunji Y, Fau GY, Suzuki T, Fau ST, Ochiai T, Ochiai T: Serum cross-linked carboxyterminal telopeptide of type I collagen (ICTP) as a prognostic tumor marker in patients with esophageal squamous cell carcinoma. Cancer 2002, 94:940-949.

19. Fau YH, Shi Q, Fau SQ, Sukov WR, Fau SW, Wiktor AE, Fau WA, Khan M, Fau KM, Sattler CA, Fau SC, Grothey A, Fau GA, Wu T-T, Fau WT, Diasio RB, Fau DR, Jenkins RB, Fau JR, Sinicrope FA, Sinicrope FA: Association of HER2/ErbB2 expression and gene amplification with pathologic features and prognosis in esophageal adenocarcinomas. Clin Cancer Res 2012, 18:546-554.

20. Buskens CJ, Van Rees BP, Sivula A, Reitsma JB, Haglund C, Bosma PJ, Offerhaus GJ, Van Lanschot JJ, Ristimaki A: Prognostic significance of 
elevated cyclooxygenase 2 expression in patients with adenocarcinoma of the esophagus. Gastroenterology 2002, 122:1800-1807.

21. Nozoe T, Ezaki T, Kabashima A, Baba H, Maehara Y: Significance of immunohistochemical expression of cyclooxygenase-2 in squamous cell carcinoma of the esophagus. Am J Surg 2005, 189:110-115.

22. Sivula A, Buskens CJ, van Rees BP, Haglund C, Offerhaus GJ, van Lanschot JJ, Ristimaki A: Prognostic role of cyclooxygenase-2 in neoadjuvant-treated patients with squamous cell carcinoma of the esophagus. Int J Canc J Int Canc 2005, 116:903-908.

23. Bhandari P, Bateman AC, Mehta RL, Stacey BS, Johnson P, Cree IA, D Nicolantonio F, Patel P: Prognostic significance of cyclooxygenase-2 (COX-2) expression in patients with surgically resectable adenocarcinoma of the oesophagus. BMC Canc 2006, 6:134.

24. Fau YM, Nam T-K, Fau NT, Lee J-S, Fau LJ, Cho S-H, Fau CS, Song J-Y, Fau SJ, Ahn S-J, Fau AS, Chung I-J, Fau Cl, Jeong J-U, Fau JJ, Chung W-K, Fau CW, Nah B-S, Nah BS: VEGF as a predictor for response to definitive chemoradiotherapy and COX-2 as a prognosticator for survival in esophageal squamous cell carcinoma. J Korean Med Sci 2011, 26:513-520. Epub 2011 Mar 2028.

25. Huang JX, Chen WC, Lin M, Zhang YL, Li FY, Song ZX, Xiao W, Chen P, Qian RY, Salminen $\mathrm{E}, \mathrm{Yu}$ H: Clinicopathological significance of cyclooxygenase-2 and cell cycle-regulatory proteins expression in patients with esophageal squamous cell carcinoma. Dis Esophagus Off J Int Soc Dis Esophagus / ISDE 2012, 25:121-129.

26. Fau US, Shimada Y, Fau SY, Watanabe G, Fau WG, Tanaka H, Fau TH, Shibagaki I, Fau SI, Miyahara T, Fau MT, Ishigami S, Fau IS, Imamura M, Imamura M: In oesophageal squamous cell carcinoma vascular endothelial growth factor is associated with p53 mutation, advanced stage and poor prognosis. Br J Cancer 1998, 77:1704-1709.

27. Fau SY, Imamura M, Fau IM, Watanabe G, Fau WG, Uchida S, Fau US, Harada H, Fau HH, Makino T, Fau MT, Kano M, Kano M: Prognostic factors of oesophageal squamous cell carcinoma from the perspective of molecular biology. $\mathrm{Br} J$ Cancer 1999, 80:1281-1288.

28. Shih CH, Ozawa S, Ando N, Ueda M, Kitajima M: Vascular endothelial growth factor expression predicts outcome and lymph node metastasis in squamous cell carcinoma of the esophagus. Clin Canc Res Offic J Am Assoc Canc Res 2000, 6:1161-1168.

29. Shimada H, Takeda A, Nabeya Y, Okazumi SI, Matsubara H, Funami Y, Hayashi H, Gunji Y, Kobayashi S, Suzuki T, Ochiai T: Clinical significance of serum vascular endothelial growth factor in esophageal squamous cell carcinoma. Cancer 2001, 92:663-669.

30. Ahn MJ, Jang SJ, Park YW, Choi JH, Oh HS, Lee CB, Paik HK, Park CK: Clinical prognostic values of vascular endothelial growth factor, microvessel density, and p53 expression in esophageal carcinomas. J Kor Med Sci 2002, 17:201-207.

31. Fau KH, Yoshikawa M, Fau YM, Miyazaki T, Fau MT, Nakajima M, Fau NM, Fukai Y, Fau FY, Masuda N, Fau MN, Fukuchi M, Fau FM, Manda R, Fau MR, Tsukada K, Fau TK, Kuwano H, Kuwano H: Expression of vascular endothelial growth factor (VEGF) and its receptors (Flt-1 and Flk-1) in esophageal squamous cell carcinoma. Anticancer Res 2002, 22:3977-3984.

32. Shimada H, Hoshino T, Okazumi S, Matsubara H, Funami Y, Nabeya Y, Hayashi H, Takeda A, Shiratori T, Uno T, et al: Expression of angiogenic factors predicts response to chemoradiotherapy and prognosis of oesophageal squamous cell carcinoma. Br J Canc 2002, 86:552-557.

33. Fau OY, Fujita H, Fau FH, Yamana H, Fau YH, Sueyoshi S, Fau SS, Shirouzu K, Shirouzu K: Expression of vascular endothelial growth factor as a prognostic factor in node-positive squamous cell carcinoma in the thoracic esophagus: long-term follow-up study. World J Surg 2003, 27:584-589. Epub 2003 Apr 2028.

34. Rosa AR, Schirmer CC, Gurski RR, Meurer L, Edelweiss MI, Kruel CD: Prognostic value of p53 protein expression and vascular endothelial growth factor expression in resected squamous cell carcinoma of the esophagus. Dis Esophagus Offic J Int Soc Dis Esophagus / ISDE 2003, 16:112-118.

35. Dreilich M, Wagenius G, Bergstrom S, Brattstrom D, Larsson A, Hesselius P, Bergqvist M: The role of cystatin $C$ and the angiogenic cytokines VEGF and bFGF in patients with esophageal carcinoma. Med Oncol 2005, 22:29-38.

36. Choi JY, Jang KT, Shim YM, Kim K, Ahn G, Lee KH, Choi Y, Choe YS, Kim BT: Prognostic significance of vascular endothelial growth factor expression and microvessel density in esophageal squamous cell carcinoma: comparison with positron emission tomography. Ann Surg Oncol 2006, 13:1054-1062.

37. Kii T, Takiuchi H, Kawabe S, Gotoh M, Ohta S, Tanaka T, Kuwakado S, Nishitani H, Katsu K: Evaluation of prognostic factors of esophageal squamous cell carcinoma (stage II-III) after concurrent chemoradiotherapy using biopsy specimens. Jpn J Clin Oncol 2007, 37:583-589.

38. Inoue A, Moriya H, Katada N, Tanabe S, Kobayashi N, Watanabe M, Okayasu I, Ohbu M: Intratumoral lymphangiogenesis of esophageal squamous cell carcinoma and relationship with regulatory factors and prognosis. Pathol Int 2008, 58:611-619.

39. Fau TC, Lee S-C, Fau LS, Tung H-J, Fau TH, Hsu H-S, Fau HH, Hsu W-H, Fau HW, Sun G-H, Fau SG, Yu C-P, Fau YC, Jin J-S, Fau JJ, Cheng Y-L, Cheng YL: Expression of hypoxia-inducible factor (HIF)-1alpha and vascular endothelial growth factor (VEGF)-D as outcome predictors in resected esophageal squamous cell carcinoma. Dis Markers 2008, 25:141-148.

40. Fau CL, Rosa ARP, Fau RA, Schirmer CC, Fau SC, Gurski RR, Fau GR, Telles JPB, Fau TJ, Mielke F, Fau MF, Meurer L, Fau ML, Edelweiss MIA, Fau EM, Kruel CDP, Kruel CD: Immunohistochemical evaluation for P53 and VEGF (Vascular Endothelial Growth Factor) is not prognostic for long term survival in end stage esophageal adenocarcinoma. Rev Col Bras Cir 2009, 36:24-34.

41. Liu P, Chen W, Zhu H, Liu B, Song S, Shen W, Wang F, Tucker S, Zhong B, Wang D: Expression of VEGF-C correlates with a poor prognosis based on analysis of prognostic factors in 73 patients with esophageal squamous cell carcinomas. Jpn J Clin Oncol 2009, 39:644-650.

42. Kozlowski M, Kowalczuk O, Milewski R, Chyczewski L, Niklinski J, Laudanski J: Serum vascular endothelial growth factors $C$ and $D$ in patients with oesophageal cancer. Eur J Cardio-thoracic Surg Offic J Eur Assoc Cardio-thoracic Surg 2010, 38:260-267.

43. Tanaka T, Ishiguro H, Kuwabara Y, Kimura M, Mitsui A, Katada T, Shiozaki M, Naganawa Y, Fujii Y, Takeyama $\mathrm{H}$ : Vascular endothelial growth factor $\mathrm{C}$ (VEGF-C) in esophageal cancer correlates with lymph node metastasis and poor patient prognosis. J Exp Clin Canc Res: CR 2010, 29:83.

44. Sun ZG, Wang Z, Liu XY, Liu FY: Mucin 1 and vascular endothelial growth factor $\mathrm{C}$ expression correlates with lymph node metastatic recurrence in patients with N0 esophageal cancer after Ivor-Lewis esophagectomy. World J Surg 2011, 35:70-77.

45. Fau MS, Miyamoto M, Fau MM, Li L, Fau LL, Kadoya M, Fau KM, Takahashi R, Fau TR, Hase R, Fau HR, Kaneko H, Fau KH, Shichinohe T, Fau ST, Kawarada Y, Fau KY, Itoh T, Fau IT, Morikawa T, et al: Immunohistochemical analysis of nuclear survivin expression in esophageal squamous cell carcinoma. Dis Esophagus: Offic J Int Soc Dis Esophagus / ISDE 2006, 19:355-359.

46. Fau RA, Pivetta M, Fau PM, Parenti A, Fau PA, laderosa GA, Fau IG, Zoso A, Fau ZA, Milan G, Fau MG, Mandruzzato S, Fau MS, Del Bianco P, Fau DBP, Ruol A, Fau RA, Zaninotto G, Fau ZG, Zanovello P, Zanovello P: Survivin in esophageal cancer: an accurate prognostic marker for squamous cell carcinoma but not adenocarcinoma. Int J Cancer 2006, 119:1717-1722.

47. Hsu KF, Lin CK, Yu CP, Tzao C, Lee SC, Lee YY, Tsai WC, Jin JS: Cortactin, fascin, and survivin expression associated with clinicopathological parameters in esophageal squamous cell carcinoma. Dis Esophagus: Offic $\mathrm{J}$ Int Soc Dis Esophagus / ISDE 2009, 22:402-408.

48. Fau HA, Vallbohmer D, Fau VD, Grimminger P, Fau GP, Metzger R, Fau MR, Prenzel KL, Fau PK, Hoelscher AH, Fau HA, Brabender J, Brabender J: Preoperative survivin mRNA detection in peripheral blood is an independent predictor of outcome in esophageal carcinoma. Pharmacogenomics 2010, 11:341-347.

49. Takeno S, Yamashita S, Takahashi Y, Ono K, Kamei M, Moroga T, Kawahara K: Survivin expression in oesophageal squamous cell carcinoma: its prognostic impact and splice variant expression. Eur J Cardio-thoracic Surg: Offic J Eur Assoc Cardio-thoracic Surg 2010, 37:440-445.

50. Sarbia M, Stahl M, zur Hausen A, Zimmermann K, Wang L, Fink U, Heep H, Dutkowski P, Willers R, Muller W, et al: Expression of p21WAF1 predicts outcome of esophageal cancer patients treated by surgery alone or by combined therapy modalities. Clin Canc Res Offic J Am Assoc Canc Res 1998, 4:2615-2623.

51. Hirai T, Kuwahara M, Yoshida K, Osaki A, Toge T: The prognostic significance of p53, p21 (Waf1/Cip1), and cyclin D1 protein expression in esophageal cancer patients. Anticancer Res 1999, 19:4587-4591.

52. Fau NS, Nakashima S, Fau NS, Matsumoto M, Fau MM, Xiangming C, Fau XC, Okumura H, Fau OH, Kijima F, Fau KF, Ishigami S, Fau IS, Takebayashi Y, Fau TY, Baba M, Fau BM, Takao S, Fau TS, Aikou T, Aikou T: Expression of p21WAF1/Cip1 in the p53-dependent pathway is related to 
prognosis in patients with advanced esophageal carcinoma. Clin Cancer Res 1999, 5:2445-2449.

53. Fau NM, Nagawa H, Fau NH, Tominaga O, Fau TO, Tsuno N, Fau TN, Hatano K, Fau HK, Kitayama J, Fau KJ, Tsuruo T, Fau TT, Domene CE, Fau DC, Muto T, Muto T: p21Waf1/Cip1 expression is a prognostic marker in curatively resected esophageal squamous cell carcinoma, but not p27Kip1, p53, or Rb. Ann Surg Oncol 1999, 6:481-488.

54. Fau MM, Furihata M, Fau FM, Kurabayashi A, Fau KA, Sasaguri S, Fau SS, Araki K, Fau AK, Hayashi H, Fau HH, Ohtsuki Y, Ohtsuki Y: Prognostic significance of serine 392 phosphorylation in overexpressed p53 protein in human esophageal squamous cell carcinoma. Oncology 2004, 67:143-150

55. Fau NT, Hayashi K, Fau HK, Ota M, Fau OM, Ide H, Fau IH, Takasaki K, Fau TK, Mitsuhashi M, Mitsuhashi M: Expression of p21(Waf1/Cip1) predicts response and survival of esophageal cancer patients treated by chemoradiotherapy. Dis Esophagus 2004, 17:315-321.

56. Fau GY, Hsu H-K, Fau HH, Chang H-C, Fau CH, Chou Y-P, Fau CY, Chiang K-H, Fau CK, Cheng J-T, Cheng JT: Deregulated p21(WAF1) overexpression impacts survival of surgically resected esophageal squamous cell carcinoma patients. Ann Thorac Surg 2005, 80:1007-1016.

57. Taghavi N, Biramijamal F, Sotoudeh M, Moaven O, Khademi H, Abbaszadegan MR, Malekzadeh R: Association of p53/p21 expression with cigarette smoking and prognosis in esophageal squamous cell carcinoma patients. World J Gastroenterol: WJG 2010, 16:4958-4967.

58. Fau AT, Furihata M, Fau FM, Ishikawa T, Fau IT, Ohtsuki Y, Fau OY, Ogoshi S, Ogoshi S: Positive correlation between p27Kip1 expression and progression of human esophageal squamous cell carcinoma. Int $J$ Cancer 1998, 79:439-443.

59. Fau IA, Shimada Y, Fau SY, Watanabe G, Fau WG, Imamura M, Imamura M: Prognostic value of p27(Kip1) and CyclinD1 expression in esophageal cancer. Oncology 1999, 57:311-317.

60. Fau YM, Tabira Y, Fau TY, Kondo K, Fau KK, Okuma T, Fau OT, Kitamura N, Kitamura N: The prognostic significance of cell cycle markers in esophageal cancer after neoadjuvant chemotherapy. Dis Esophagus: Offic J Int Soc Dis Esophagus / ISDE 1999, 12:120-127.

61. Fau SA, Doki Y, Fau DY, Tsujinaka T, Fau TT, Shiozaki H, Fau SH, Inoue M, Fau IM, Yano M, Fau YM, Kawanishi K, Fau KK, Monden M, Monden M: Loss of p27 (KIP1) expression predicts poor prognosis in patients with esophageal squamous cell carcinoma. Oncology 2000, 58:152-158.

62. Fau SH, Doki Y, Fau DY, Kawanishi K, Fau KK, Shamma A, Fau SA, Yano M, Fau YM, Inoue M, Fau IM, Monden M, Monden M: Clinical application of malignancy potential grading as a prognostic factor of human esophageal cancers. Surgery 2000, 127:552-561.

63. Nishioka K, Doki Y, Shiozaki H, Yamamoto H, Tamura S, Yasuda T, Fujiwara Y, Yano M, Miyata $\mathrm{H}$, Kishi $\mathrm{K}$, et al: Clinical significance of CDC25A and $\mathrm{CDC} 25 \mathrm{~B}$ expression in squamous cell carcinomas of the oesophagus. $\mathrm{Br} \mathrm{J}$ Canc 2001, 85:412-421.

64. Fau SM, Stahl M, Fau SM, Fink U, Fau FU, Heep H, Fau HH, Dutkowski $P$, Fau DP, Willers R, Fau WR, Seeber S, Fau SS, Gabbert HE, Gabbert HE: Prognostic significance of cyclin D1 in esophageal squamous cell carcinoma patients treated with surgery alone or combined therapy modalities. Int J Canc 1999, 84:86-91.

65. Research Committee on Malignancy of Esophageal Cancer, Japanese Society for Esophageal Diseases: Prognostic significance of CyclinD1 and E-Cadherin in patients with esophageal squamous cell carcinoma: multiinstitutional retrospective analysis. J Am Coll Surg 2001, 192:708-718.

66. Fau IM, Sakatani T, Fau ST, Ueta T, Fau UT, Kaibara N, Kaibara N: Cyclin D1 expression and retinoblastoma gene protein (pRB) expression in esophageal squamous cell carcinoma. J Canc Res Clin Oncol 2001, 127:531-536.

67. Fau NS, Onda M, Fau OM, Sasajima K, Fau SK, Makino H, Fau MH, Yamashita K, Fau YK, Takubo K, Fau TK, Miyashita M, Miyashita M: Cyclin D1 overexpression as a prognostic factor in patients with esophageal carcinoma. J Surg Oncol 2001, 78:208-214.

68. Fau SM, Aoki T, Fau AT, Sato S, Fau SS, Takagi Y, Fau TY, Osaka Y, Fau OY, Koyanagi Y, Fau KY, Hatooka S, Fau HS, Shinoda M, Shinoda M: Cell cycleregulated factors in esophageal cancer. Dis Esophagus Offic J Int Soc Dis Esophagus / ISDE 2002, 15:149-154.

69. Fau GD, Sturm I, Fau SI, Hemmati P, Fau HP, Hermann S, Fau HS, Hauptmann S, Fau HS, Wurm R, Fau WR, Budach V, Fau BV, Dorken B, Fau DB, Lorenz M, Fau LM, Daniel PT, Daniel PT: Multigene analysis of Rb pathway and apoptosis control in esophageal squamous cell carcinoma identifies patients with good prognosis. Int J Cancer 2003, 103:445-454.

70. Fau FM, Fukai Y, Fau FY, Kimura H, Fau KH, Sohda M, Fau SM, Miyazaki T, Fau MT, Nakajima M, Fau NM, Masuda N, Fau MN, Tsukada K, Fau TK, Kato H, Fau KH, Kuwano H, Kuwano H: Prolyl isomerase Pin1 expression predicts prognosis in patients with esophageal squamous cell carcinoma and correlates with cyclinD1 expression. Int J Oncol 2006, 29:329-334.

71. Fau TH, Ichikawa D, Fau ID, Komatsu S, Fau KS, Tsujiura M, Fau TM, Kosuga T, Fau KT, Deguchi K, Fau DK, Konishi H, Fau KH, Morimura R, Fau MR, Shiozaki A, Fau SA, Fujiwara H, Fau FH, Okamoto $K$, et al: Prediction of CCND1 amplification using plasma DNA as a prognostic marker in oesophageal squamous cell carcinoma. Br J Canc 2010, 102:1378-1383. Epub 2010 Apr 1313.

72. Fau WM, Chen G, Fau CG, An SJ, Fau AS, Chen ZH, Fau CZ, Huang ZM, Fau HZ, Xiao P, Fau XP, Ben XS, Fau BX, Xie Z, Fau XZ, Chen SL, Fau CS, Luo DL, Fau LD, Tang JM, et al: Prognostic significance of cyclinD1 amplification and the co-alteration of cyclinD1/pRb/ppRb in patients with esophageal squamous cell carcinoma. Dis Esophagus 2012, 25:664-670. doi:610.1111/j.14422050.2011.01291.x. Epub 02011 Dec 01299.

73. Chanvitan A, Nekarda H, Casson AG: Prognostic value of DNA index, S-phase fraction and p53 protein accumulation after surgical resection of esophageal squamous-cell carcinomas in Thailand. Int J Canc J Int Canc 1995, 63:381-386.

74. Fau CA, Tammemagi M, Fau TM, Eskandarian S, Fau ES, Redston M, Fau RM, McLaughlin J, Fau MLJ, Ozcelik H, Ozcelik H: p53 alterations in oesophageal cancer: association with clinicopathological features, risk factors, and survival. Mol Pathol 1998, 51:71-79.

75. Pomp J, Davelaar J, Blom J, van Krimpen C, Zwinderman A, Quint W Immerzeel J: Radiotherapy for oesophagus carcinoma: the impact of p53 on treatment outcome. Radiother Oncol J Eur Soc Ther Radiol Oncol 1998, 46:179-184.

76. Fau KA, Kato H, Fau KH, Tachimori Y, Fau TY, Watanabe H, Fau WH, Nakanishi Y, Fau NY, Kondo H, Fau KH, Yamaguchi H, Fau YH, Gotoda T, Fau GT, Muro K, Fau MK, Matsumura Y, Matsumura Y: No prognostic significance of p53 expression in esophageal squamous cell carcinoma. J Surg Oncol 1999, 72:94-98.

77. Kuwahara M, Hirai $T$, Yoshida $K$, Yamashita $Y$, Hihara J, Inoue $H$, Toge $T$ : p53, p21(Waf1/Cip1) and cyclin D1 protein expression and prognosis in esophageal cancer. Dis Esophagus Offic J Int Soc Dis Esophagus / ISDE 1999, 12:116-119.

78. Fau IM, Oka S, Fau OS, Gomyo Y, Fau GY, Tsujitani S, Fau TS, Maeta M, Fau MM, Kaibara N, Kaibara N: Combined analysis of p53 and retinoblastoma protein expressions in esophageal cancer. Ann Thorac Surg 2000, 70:913-917.

79. Schneider PM, Stoeltzing O, Roth JA, Hoelscher AH, Wegerer S, Mizumoto S, Becker K, Dittler HJ, Fink U, Siewert JR: P53 mutational status improves estimation of prognosis in patients with curatively resected adenocarcinoma in Barrett's esophagus. Clin Canc Res Offic J Am Assoc Canc Res 2000, 6:3153-3158.

80. Fau AT, Harpole DH Jr, Fau HD Jr, Reed CE, Fau RC, Allegra C, Fau AC, Moore MB, Fau MM, Herndon JE 2nd, Fau HJ 2nd, D'Amico TA, D'Amico TA: Tumor marker expression is predictive of survival in patients with esophageal cancer. Ann Thorac Surg 2001, 72:859-866.

81. Fau BA, Bergqvist M, Fau BM, Brattstrom D, Fau BD, Hesselius P, Fau HP, Larsson A, Fau LA, Brodin O, Fau BO, Wagenius G, Wagenius G: Serum p53 autoantibodies as prognostic marker in patients with oesophageal carcinoma. Anticancer Res 2001, 21:4141-4145.

82. Fau MO, Takeda A, Fau TA, Ting-Leig L, Fau T-LL, Shinnichi O, Fau SO, Hisahiro M, Fau HM, Yutaka F, Fau YF, Yoshihiro N, Fau YN, Kobayashi S, Fau KS, Gunji Y, Fau GY, Suzuki T, Fau ST, Takenori O, et al: Prognostic significance of thymidine phosphorylase and p53 co-expression in esophageal squamous cell carcinoma. Oncol Rep 2002, 9:23-28.

83. Noguchi T, Takeno S, Shibata T, Uchida Y, Yokoyama S, Muller W: Expression of heat shock protein 70 in grossly resected esophageal squamous cell carcinoma. Ann Thorac Surg 2002, 74:222-226.

84. Shimada H, Nabeya Y, Okazumi S, Matsubara H, Funami Y, Shiratori T, Hayashi H, Takeda A, Ochiai T: Prognostic significance of serum p53 antibody in patients with esophageal squamous cell carcinoma. Surgery 2002, 132:41-47

85. Fau TS, Noguchi T, Fau NT, Kikuchi R, Fau KR, Uchida Y, Fau UY, Yokoyama S, Fau YS, Muller W, Muller W: Prognostic value of cyclin B1 in patients with esophageal squamous cell carcinoma. Cancer 2002, 94:2874-2881. 
86. Gibson MK, Abraham SC, Wu TT, Burtness B, Heitmiller RF, Heath E, Forastiere A: Epidermal growth factor receptor, p53 mutation, and pathological response predict survival in patients with locally advanced esophageal cancer treated with preoperative chemoradiotherapy. Clin Canc Res Offic J Am Assoc Canc Res 2003, 9:6461-6468.

87. Ikeguchi M, Yamaguchi K, Kaibara N: Survivin gene expression positively correlates with proliferative activity of cancer cells in esophageal cancer. Tumour Biol J Int Soc Oncodevelopmental Biol Med 2003, 24:40-45.

88. Fau KC, Imada T, Fau IT, Yamada R, Fau YR, Hatori S, Fau HS, Kinbara K, Fau KK, Watai K, Fau WK, Akiyama H, Fau AH, Nomura M, Fau NM, Matsuda G, Fau MG, Otsuka Y, Fau OY, Ono H, et al: Prognostic factors after chemoradiotherapy for patients with inoperable esophageal squamous cell carcinoma. Hepatogastroenterology 2006, 53:366-371.

89. Fau HP, Li AF-Y, Fau LA, Wang Y-C, Fau WY, Hsieh C-C, Fau HC, Huang M-H, Fau HM, Hsu W-H, Fau HW, Hsu H-S, Hsu HS: Reduced membranous beta-catenin protein expression is associated with metastasis and poor prognosis in squamous cell carcinoma of the esophagus. J Thorac Cardiovasc Surg 2008, 135:1029-1035.

90. Fau SH, Shiratori T, Fau ST, Takeda A, Fau TA, Matsushita K, Fau MK, Okazumi S, Fau OS, Akutsu Y, Fau AY, Matsubara H, Fau MH, Nomura F, Fau NF, Ochiai T, Ochiai T: Perioperative changes of serum p53 antibody titer is a predictor for survival in patients with esophageal squamous cell carcinoma. World J Surg 2008, 33:272-277.

91. Fau CT, Hsu P-K, Fau HP, Li AF-Y, Fau LA, Hung IC, Fau HI, Huang M-H, Fau HM, Hsu H-S, Hsu HS: Correlation of p53, MDM2 and p14(ARF) protein expression in human esophageal squamous cell carcinoma. J Cancer Res Clin Oncol 2009, 135:1577-1582. Epub 2009 Jun 1572.

92. Fau OH, Kita Y, Fau KY, Yokomakura N, Fau YN, Uchikado Y, Fau UY, Setoyama T, Fau ST, Sakurai H, Fau SH, Omoto I, Fau OI, Matsumoto M, Fau MM, Owaki T, Fau OT, Ishigami S, Fau IS, Natsugoe S, Natsugoe S: Nuclear expression of 14-3-3 sigma is related to prognosis in patients with esophageal squamous cell carcinoma. Anticancer Res 2010, 30:5175-5179.

93. Fau YM, Miyata H, Fau MH, Fujiwara Y, Fau FY, Takiguchi S, Fau TS, Nakajima K, Fau NK, Nishida T, Fau NT, Yasuda T, Fau YT, Matsuyama J, Fau MJ, Mori M, Fau MM, Doki Y, Doki Y: p53 genotype predicts response to chemotherapy in patients with squamous cell carcinoma of the esophagus. Ann Surg Oncol 2010, 17:634-642. Epub 2009 Nov 2026.

94. Fau YC, Tsao Y-P, Fau TY, Chen PC-H, Fau CP, Wu Y-C, Fau WY, Liu J-H, Fau L, Pan C-C, Fau PC, Liu C-Y, Fau LC, Tzeng C-H, Fau TC, Chen P-M, Fau $C P$, Chen $Y-J$, Fau $C Y$, Lin $C-H$, et al: PML protein as a prognostic molecular marker for patients with esophageal squamous cell carcinomas receiving primary surgery. J Surg Oncol 2011, 103:761-767. 710.1002/ jso.21855. Epub 22011 Jan 21815

95. Blanchard P, Quero L, Pacault V, Schlageter MH, Baruch-Hennequin V, Hennequin C: Prognostic significance of anti-p53 and anti-KRas circulating antibodies in esophageal cancer patients treated with chemoradiotherapy. BMC Canc 2012, 12:119.

96. Fau NT, Nekarda H, Fau NH, Hoelscher AH, Fau HA, Bollschweiler E, Fau BE, Harbeck N, Fau HN, Becker K, Fau BK, Siewert JR, Siewert JRFAUHN, Harbec N: Prognostic value of DNA ploidy and c-erbB-2 oncoprotein overexpression in adenocarcinoma of Barrett's esophagus. Cancer 1994, 73:1785-1794.

97. Fau MK, Kono K, Fau KK, Hanawa M, Fau HM, Mitsui F, Fau MF, Sugai H, Fau SH, Miyagawa N, Fau MN, Ooi A, Fau OA, Fujii H, Fujii H: Frequencies of HER-2/neu expression and gene amplification in patients with oesophageal squamous cell carcinoma. Br J Cancer 2005, 92:1253-1260.

98. Fau DM, Wanders A, Fau WA, Brattstrom D, Fau BD, Bergstrom S, Fau BS, Hesselius P, Fau HP, Wagenius G, Fau WG, Bergqvist M, Bergqvist M: HER-2 overexpression (3+) in patients with squamous cell esophageal carcinoma correlates with poorer survival. Dis Esophagus 2006, 19:224-231.

99. Fau RS, Weis R, Fau WR, Braselmann H, Fau BH, Feith M, Fau FM, Stein HJ, Fau SH, Langer R, Fau LR, Hutzler P, Fau HP, Hausmann M, Fau HM, Lassmann S, Fau LS, Siewert JR, Fau S Jr, Hofler H, et al: Significance of HER2 low-level copy gain in Barrett's cancer: implications for fluorescence in situ hybridization testing in tissues. Clin Cancer Res 2007, 13:5115-5123.

100. Fau BD, Wolff C, Fau WC, Langer R, Fau LR, Schuster T, Fau ST, Feith M, Fau FM, Slotta-Huspenina J, Fau S-HJ, Malinowsky K, Fau MK, Becker K-F, Becker KF: Discovery of new molecular subtypes in oesophageal adenocarcinoma. PloS One 2011, 6:e23985. 10.1371/journal.pone.0023985. Epub 2011 Sep 23.

101. Fau KH, Nakajima M, Fau NM, Masuda N, Fau MN, Faried A, Fau FA, Sohda M, Fau SM, Fukai Y, Fau FY, Miyazaki T, Fau MT, Fukuchi M, Fau FM, Tsukada K, Fau TK, Kuwano H, Kuwano H: Expression of RCAS1 in esophageal squamous cell carcinoma is associated with a poor prognosis. J Surg Oncol 2005, 90:89-94.

102. Fau FD, Nilbert M, Fau NM, Oberg S, Fau OS, Johansson J, Johansson J: Prognostic value of cell adhesion in esophageal adenocarcinomas. Dis Esophagus 2008, 21:97-102.

103. Fau ZX, Li H, Fau LH, Chen H, Fau CH, Liu Y-X, Fau LY, Zhang L-H, Fau ZL, Liu S-X, Fau LS, Feng Q-L, Feng QL: Expression of e-cadherin and betacatenin in human esophageal squamous cell carcinoma: relationships with prognosis. World J Gastroenterol 2003, 9:225-232.

104. Fau SY, Hashimoto Y, Fau HY, Kan T, Fau KT, Kawamura J-i, Fau KJ, Okumura T, Fau OT, Soma T, Fau ST, Kondo K, Fau KK, Teratani N, Fau TN, Watanabe G, Fau WG, Ino Y, Fau IY, Sakamoto M, et al: Prognostic significance of dysadherin expression in esophageal squamous cell carcinoma. Oncology 2004. City.

105. Fau TS, Noguchi T, Fau NT, Fumoto S, Fau FS, Kimura Y, Fau KY, Shibata T, Fau ST, Kawahara K, Kawahara K: E-cadherin expression in patients with esophageal squamous cell carcinoma: promoter hypermethylation, Snail overexpression, and clinicopathologic implications. Am J Clin Pathol 2004, 122:78-84.

106. Natsugoe S, Uchikado Y, Okumura H, Matsumoto M, Setoyama T, Tamotsu K, Kita Y, Sakamoto A, Owaki T, Ishigami S, Aikou T: Snail plays a key role in E-cadherin-preserved esophageal squamous cell carcinoma. Oncol Rep 2007, 17:517-523.

107. Fau ST, Natsugoe S, Fau NS, Okumura H, Fau OH, Matsumoto M, Fau MM, Uchikado Y, Fau UY, Yokomakura N, Fau YN, Ishigami S, Fau IS, Aikou T, Aikou T: Alpha-catenin is a significant prognostic factor than E-cadherin in esophageal squamous cell carcinoma. J Surg Oncol 2007, 95:148-155.

108. Fau SK, Natsugoe S, Fau NS, Ishigami S, Fau IS, Matsumoto M, Fau MM, Okumura H, Fau OH, Setoyama T, Fau ST, Uchikado Y, Fau UY, Kita Y, Fau KY, Tamotsu K, Fau TK, Sakamoto A, Fau SA, Owaki T, et al: Significance of Twist expression and its association with E-cadherin in esophageal squamous cell carcinoma. J Exp Clin Cancer Res 2009, 28:158.

109. Fau CY, Law S, Fau LS, Kwong DLW, Fau KD, Luk JM, Luk JM: Serum soluble E-cadherin is a potential prognostic marker in esophageal squamous cell carcinoma. Dis Esophagus 2011, 24:49-55. 10.1111/j.1442-2050.2010.01093.x. Epub 02010 Aug 01030.

110. Fau NT, Saeki H, Fau SH, Sugimachi K, Sugimachi K: Significance of preoperative elevation of serum C-reactive protein as an indicator of prognosis in esophageal carcinoma. Am J Surg 2001, 182:197-201.

111. Fau IM, Natsugoe S, Fau NS, Ueno S, Fau US, Baba M, Fau BM, Aikou T, Aikou T: Significant host- and tumor-related factors for predicting prognosis in patients with esophageal carcinoma. Ann Surg 2003, 238:197-202.

112. Fau NT, Korenaga D, Fau KD, Futatsugi M, Fau FM, Saeki H, Fau SH, Maehara Y, Fau MY, Sugimachi K, Sugimachi K: Immunohistochemical expression of C-reactive protein in squamous cell carcinoma of the esophagus significance as a tumor marker. Cancer Lett 2003, 192:89-95.

113. Fau SH, Nabeya Y, Fau NY, Okazumi S-I, Fau OS, Matsubara H, Fau MH, Shiratori T, Fau ST, Aoki T, Fau AT, Sugaya M, Fau SM, Miyazawa Y, Fau MY, Hayashi H, Fau HH, Miyazaki S-I, Fau MS, Ochiai T, Ochiai T: Elevation of preoperative serum C-reactive protein level is related to poor prognosis in esophageal squamous cell carcinoma. J Surg Oncol 2003, 83:248-252.

114. Fau Gl, Dirksen K, Fau DK, Messow C-M, Fau MC, Junginger T, Junginger T: Significance of preoperative C-reactive protein as a parameter of the perioperative course and long-term prognosis in squamous cell carcinoma and adenocarcinoma of the oesophagus. World J Gastroenterol 2006, 12:3746-3750.

115. Fau WC, Hsieh M-J, Fau HM, Chiu Y-C, Fau CY, Li S-H, Fau LS, Huang H-W, Fau HH, Fang F-M, Fau FF, Huang Y-J, Huang YJ: Higher serum C-reactive protein concentration and hypoalbuminemia are poor prognostic indicators in patients with esophageal cancer undergoing radiotherapy. Radiother Oncol 2009, 92:270-275. Epub 2009 Feb 2003.

116. Fau ZU, Forberger J, Fau FJ, Rajcic B, Fau RB, Langton C, Fau LC, Jamieson GG, Jamieson GG: Association of C-reactive protein levels and long-term survival after neoadjuvant therapy and esophagectomy for esophageal cancer. J Gastrointest Surg 2010, 14:462-469. Epub 2009 Nov 2025.

117. Fau NT, Motoyama S, Fau MS, Maruyama K, Fau MK, Usami S, Fau US, Sato Y, Fau SY, Miura M, Fau MM, Hinai Y, Fau HY, Saito H, Fau SH, Minamiya Y, Fau MY, Murata K, Fau MK, Ogawa J-i, Ogawa J: Tumoral CRP expression in thoracic esophageal squamous cell cancers is associated with poor outcomes. Surg Today 2012, 42:652-658. Epub 2012 Feb 2021. 
118. Shimada H, Nabeya Y, Okazumi S, Matsubara H, Shiratori T, Gunji Y, Kobayashi S, Hayashi H, Ochiai T: Prediction of survival with squamous cell carcinoma antigen in patients with resectable esophageal squamous cell carcinoma. Surgery 2003, 133:486-494.

119. Kosugi S, Nishimaki T, Kanda T, Nakagawa S, Ohashi M, Hatakeyama K: Clinical significance of serum carcinoembryonic antigen, carbohydrate antigen 19-9, and squamous cell carcinoma antigen levels in esophageal cancer patients. World J Surg 2004, 28:680-685.

120. Shimada Y, Watanabe G, Kawamura J, Soma T, Okabe M, Ito T, Inoue H, Kondo M, Mori Y, Tanaka E, Imamura M: Clinical significance of osteopontin in esophageal squamous cell carcinoma: comparison with common tumor markers. Oncology 2005, 68:285-292.

121. Cao M, Yie SM, Wu SM, Chen S, Lou B, He X, Ye SR, Xie K, Rao L, Gao E, Ye NY: Detection of survivin-expressing circulating cancer cells in the peripheral blood of patients with esophageal squamous cell carcinoma and its clinical significance. Clin Exp Metastasis 2009, 26:751-758.

122. Fau BD, Wagenius G, Fau WG, Sandstrom P, Fau SP, Dreilich M, Fau DM, Bergstrom S, Fau BS, Goike H, Fau GH, Hesselius P, Fau HP, Bergqvist M, Bergqvist M: Newly developed assay measuring cytokeratins 8, 18 and 19 in serum is correlated to survival and tumor volume in patients with esophageal carcinoma. Dis Esophagus 2005, 18:298-303.

123. Valencia Julve J, Alonso Orduna V, Esco Baron R, Lopez-Mata M, Mendez Villamon A: Influence of hemoglobin levels on survival after radical treatment of esophageal carcinoma with radiotherapy. Clin Translational Oncol Offic Publ Federation Spanish Oncol Soc Nat Canc Inst Mexico 2006, 8:22-30.

124. Zhao KL, Liu G, Jiang GL, Wang Y, Zhong LJ, Yao WQ, Guo XM, Wu GD, Zhu LX, Shi XH: Association of haemoglobin level with morbidity and mortality of patients with locally advanced oesophageal carcinoma undergoing radiotherapy-a secondary analysis of three consecutive clinical phase III trials. Clin Oncol (R Coll Radiol) 2006, 18:621-627.

125. Rades D, Golke H, Schild SE, Kilic E: Impact of VEGF and VEGF receptor 1 (FLT1) expression on the prognosis of stage III esophageal cancer patients after radiochemotherapy. Strahlenther Onkol Organ Deutschen Rontgengesellschaft [et al] 2008, 184:416-420.

126. Zenda S, Hironaka S, Boku N, Yamazaki K, Yasui H, Fukutomi A, Yoshino T, Onozawa $Y$, Nishimura T: Impact of hemoglobin level on survival in definitive chemoradiotherapy for T4/M1 lymph node esophageal cancer. Dis Esophagus Offic J Int Soc Dis Esophagus / ISDE 2008, 21:195-200.

127. Gould Rothberg BE, Bracken MB, Rimm DL: Tissue biomarkers for prognosis in cutaneous melanoma: a systematic review and meta-analysis. J Natl Canc Inst 2009, 101:452-474.

128. Fau HH, Philipson P, Fau PP, Chen R, Fau CR, Fitzpatrick NK, Fau FN, Damant J, Fau DJ, Shipley M, Fau SM, Abrams KR, Fau AK, Moreno S, Fau MS, McAllister KSL, Fau MAK, Palmer S, Fau PS, Kaski JC, et al: Evaluating the quality of research into a single prognostic biomarker: a systematic review and meta-analysis of 83 studies of C-reactive protein in stable coronary artery disease. PloS Med 2010, 7:e1000286. 10.1371/journal.pmed.1000286.

129. Fau MJ, Wiksten J-P, Fau WJ, Kokkola A, Fau KA, Nordling S, Fau NS, Ristimaki A Fau RA, Haglund C, Haglund C: COX-2 is associated with proliferation and apoptosis markers and serves as an independent prognostic factor in gastric cancer. Tumour Biol 2010, 31:1-7. 10.1007/s13277-13009-10001-13274. Epub 12009 Dec 13218

130. Chen J, Li T, Wu Y, He L, Zhang L, Shi T, Yi Z, Liu M, Pang X: Prognostic significance of vascular endothelial growth factor expression in gastric carcinoma: a meta-analysis. J Canc Res Clin Oncol 2011, 137:1799-1812.

131. Des Guetz G, Uzzan B, Nicolas P, Cucherat M, Morere JF, Benamouzig R, Breau $\lrcorner$, Perret GY: Microvessel density and VEGF expression are prognostic factors in colorectal cancer. Meta-analysis of the literature. $\mathrm{Br} J$ Canc 2006, 94:1823-1832.

132. Altieri DC: Survivin, cancer networks and pathway-directed drug discovery. Nat Rev Canc 2008, 8:61-70.

133. Lee MH, Yang HY: Negative regulators of cyclin-dependent kinases and their roles in cancers. Cell Mol life Sci: CMLS 2001, 58:1907-1922.

134. Chu IM, Hengst L, Slingerland JM: The Cdk inhibitor p27 in human cancer: prognostic potential and relevance to anticancer therapy. Nat Rev Canc 2008, 8:253-267.

135. Al-Maghrabi J, Al-Ahwal M, Buhmeida A, Syrjanen K, Sibyani A, Emam E, Ghanim A, Al-Qahtani M: Expression of cell cycle regulators p21 and p27 as predictors of disease outcome in colorectal carcinoma. $J$ Gastrointest Canc 2012, 43:279-287.
136. Hugo H, Ackland ML, Blick T, Lawrence MG, Clements JA, Williams ED, Thompson EW: Epithelial-mesenchymal and mesenchymal-epithelial transitions in carcinoma progression. J Cell Physiol 2007, 213:374-383.

137. Hirohashi S, Kanai Y: Cell adhesion system and human cancer morphogenesis. Canc Sci 2005, 94:575-581.

138. Gaarenstroom KN, Kenter GG, Bonfrer JMG, Korse CM, Van de Vijver MJ, Fleuren GJ, Trimbos JB: Can initial serum cyfra 21-1, SCC antigen, and TPA levels in squamous cell cervical cancer predict lymph node metastases or prognosis? Gynecol Oncol 2000, 77:164-170.

139. Hatzakis KD, Froudarakis ME, Bouros D, Tzanakis N, Karkavitsas N, Siafakas NM: Prognostic value of serum tumor markers in patients with lung cancer. Respiration 2002, 69:25-29.

140. Mahmoud FA, Rivera NI: The role of C-reactive protein as a prognostic indicator in advanced cancer. Curr Oncol Rep 2002, 4:250-255.

141. Begg CB, Mazumdar M: Operating characteristics of a rank correlation test for publication bias. Biometrics 1994, 50:1088-1101.

doi:10.1186/1471-2407-13-539

Cite this article as: Chen et al:: Systematic review and meta-analysis of tumor biomarkers in predicting prognosis in esophageal cancer. BMC Cancer 2013 13:539.

\section{Submit your next manuscript to BioMed Central and take full advantage of:}

- Convenient online submission

- Thorough peer review

- No space constraints or color figure charges

- Immediate publication on acceptance

- Inclusion in PubMed, CAS, Scopus and Google Scholar

- Research which is freely available for redistribution

Submit your manuscript at www.biomedcentral.com/submit
C) Biomed Central 